\title{
Fractionation of iron species and iron isotopes in the Baltic Sea euphotic zone
}

\author{
J. Gelting ${ }^{1}$, E. Breitbarth ${ }^{1,2,3}$, B. Stolpe ${ }^{2,4}$, M. Hassellö ${ }^{2}$, and J. Ingri ${ }^{1}$ \\ ${ }^{1}$ Division of Applied Geology, Luleå University of Technology, Sweden \\ ${ }^{2}$ Department of Chemistry, University of Gothenburg, Gothenburg, Sweden \\ ${ }^{3}$ Department of Chemistry, University of Otago, Dunedin, New Zealand \\ ${ }^{4}$ Department of Marine Science, University of Southern Mississippi, Hattiesburg, USA
}

Received: 10 June 2009 - Published in Biogeosciences Discuss.: 2 July 2009

Revised: 25 June 2010 - Accepted: 27 July 2010 - Published: 23 August 2010

\begin{abstract}
To indentify sources and transport mechanisms of iron in a coastal marine environment, we conducted measurements of the physiochemical speciation of $\mathrm{Fe}$ in the euphotic zone at three different locations in the Baltic Sea. In addition to sampling across a salinity gradient, we conducted this study over the spring and summer season. Moving from the riverine input characterized low salinity Bothnian Sea, via the Landsort Deep near Stockholm, towards the Gotland Deep in the Baltic Proper, total Fe concentrations averaged 114,44 , and $15 \mathrm{nM}$, respectively. At all three locations, a decrease in total $\mathrm{Fe}$ of $80-90 \%$ from early spring to summer was observed. Particulate $\mathrm{Fe}(\mathrm{PFe})$ was the dominating phase at all stations and accounted for $75-85 \%$ of the total Fe pool on average. The $\mathrm{Fe}$ isotope composition $\left(\delta^{56} \mathrm{Fe}\right)$ of the PFe showed constant positive values in the Bothnian Sea surface waters $(+0.08$ to $+0.20 \%$ o $)$. Enrichment of heavy Fe in the Bothnian Sea PFe is possibly associated to input of aggregated land derived Fe-oxyhydroxides and oxidation of dissolved $\mathrm{Fe}(\mathrm{II})$. At the Landsort Deep the isotopic fractionation of PFe changed between $-0.08 \%$ o to $+0.28 \%$ over the sampling period. The negative values in early spring indicate transport of PFe from the oxic-anoxic boundary at $\sim 80 \mathrm{~m}$ depth. The average colloidal iron fraction $(\mathrm{CFe})$ showed decreasing concentrations along the salinity gradient; Bothnian Sea $15 \mathrm{nM}$; Landsort Deep $1 \mathrm{nM}$, and Gotland Deep $0.5 \mathrm{nM}$. Field Flow Fractionation data indicate that the main colloidal carrier phase for $\mathrm{Fe}$ in the Baltic Sea is a carbon-rich fulvic acid associated compound, likely of riverine origin. A strong positive correlation between PFe and chl- $a$ indicates that cycling of suspended $\mathrm{Fe}$ is at least partially controlled
\end{abstract}

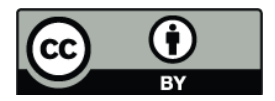

Correspondence to: J. Gelting

(johan.gelting@1tu.se) by primary production. However, this relationship may not be dominated by active uptake of Fe into phytoplankton, but instead may reflect scavenging and removal of PFe during phytoplankton sedimentation.

\section{Introduction}

Iron $(\mathrm{Fe})$, the fourth most abundant element of the Earth's crust, has a dynamic and fundamental role in all earth surface systems. It is essential as micronutrient to all living organisms, as it is required for photosynthesis and respiratory (Whitfield, 2001) electron transport, for nitrate, nitrite and sulphate reduction and for nitrogen fixation. The role of iron as a regulating element for phytoplankton in large regions of the world ocean, also referred to as the High Nutrient, Low Chlorophyll regions, is now well established (de Baar et al., 2005; Boyd et al., 2007). In costal and estuarine regions Fe depletion is not considered at first hand, but the actual bioavailable amount of iron may be very low due to a high degree of organic complexation (Rue and Bruland, 1995; Hutchins and Bruland, 1998; Bruland et al., 2001; Özturk et al., 2002). Furthermore, not only low Fe open ocean systems are of interest for the understanding of Fe biogeochemistry, but also knowledge about Fe cycling in high-Fe regimes (Boyd et al., 2007). An improved understanding of estuarine processes controlling $\mathrm{Fe}$ speciation in the Baltic Sea is also of general use for understanding and estimating fluxes of $\mathrm{Fe}$ to other coastal waters and into the open ocean. The Baltic Sea serves as an excellent model system for such a study as it is characterized by high riverine input, thus also by a strong salinity gradient, and further by a central deep basin and a connection with limited exchange to the open ocean via the

Published by Copernicus Publications on behalf of the European Geosciences Union. 

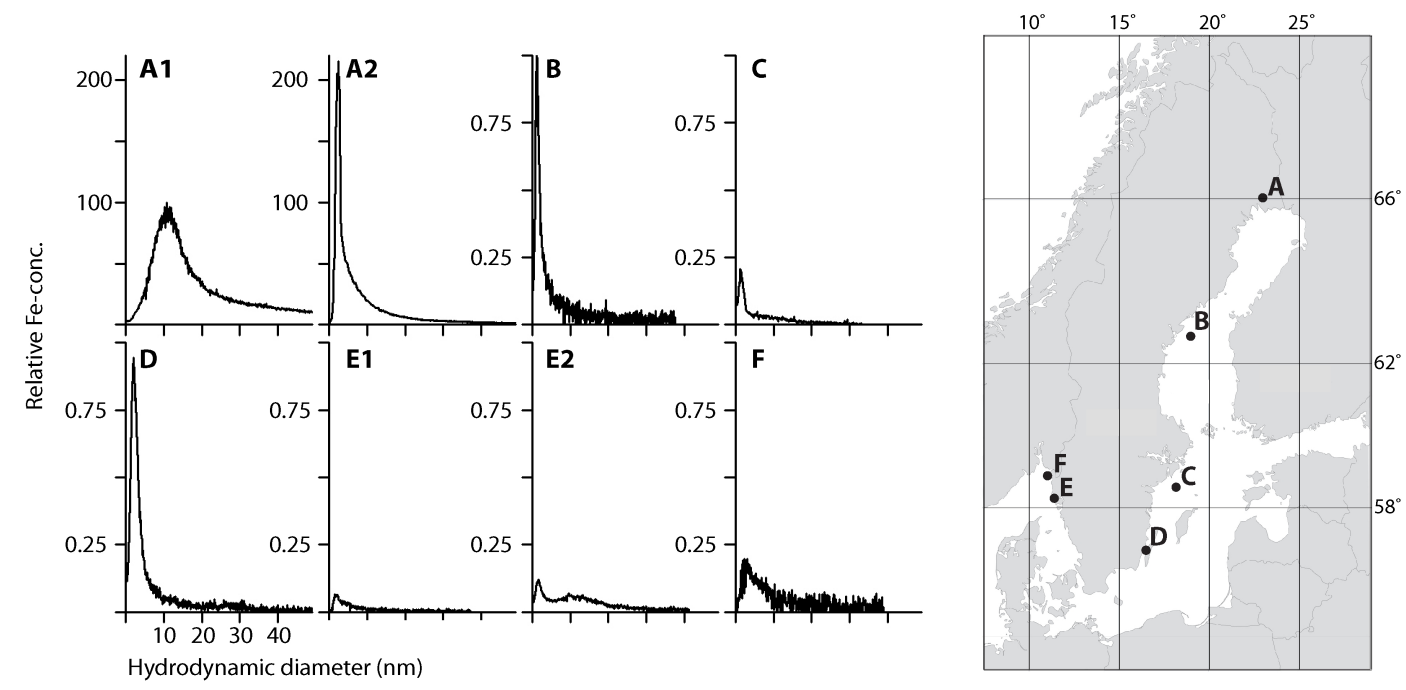

Fig. 1. $0.5-50 \mathrm{~nm}$ colloidal size spectra of iron is shown to the left (A1-F). The letters correspond to the locations on the map (A-F) where the samples were taken. For station A and E, two different samples are shown in the left figure (A1+A2 and E1+E2 respectively). A. Kalix River at Kamlunge on 9 April 2002 (A1) and during maximum spring flood on 1 May 2002 (A2). B. Bothnian Sea at 5 m depth on 19 July 2006. C. Baltic Sea (offshore) at $5 \mathrm{~m}$ depth on 14 April 2004. D. Baltic Sea at Kalmar Sound (near shore) at $1 \mathrm{~m}$ depth on 5 September 2005, E. Gullmarsfjord at $10 \mathrm{~m}$ depth on 21 March 2005 (E1) and on 22 June 2005 (E2). F. Skagerrak Sea (nearshore) at $1 \mathrm{~m}$ depth on 30 June 2005. Relative Fe-concentrations shown on y-axis are proportional to, but not equal to, concentrations in the samples.

Skagerrak. The aim of the present study was to identify key mechanisms of $\mathrm{Fe}$ transport and $\mathrm{Fe}$ cycling across a salinity gradient, taking seasonal biological processes into account.

To further elucidate Fe input and Fe speciation in coastal waters, colloidal size distributions of iron (Fig. 1) and other elements have been determined by Field Flow Fractionation coupled to Inductively Coupled Plasma Mass Spectrometry (FFF-ICPMS) in a number of studies, ranging from river water (Dahlqvist et al., 2007; Lyvén et al., 2003), and surface water from the brackish Bothnian Sea (Salinity $~ 4.7$ ) through the Baltic Proper (this study, Salinity $\geq 7$ ) and the Skagerrak coast (Salinity $>20$ ) at the North Sea boundary (Stolpe and Hassellöv, 2010). In river water, colloid-associated iron is mainly distributed between 0.5-4 nm macromolecules of humic-type fluorescent organic matter (presumed fulvic acid) and 3-50 nm iron rich colloids (presumed Fe(III)-hydroxide/oxyhydroxide; Hassellöv and von der Kammer, 2008). The occurrence and relative importance of the iron oxyhydroxide colloids in relation to iron complexed by organic matter (fulvic acids) depend on catchment geology and water chemistry (e.g. pH, dissolved organic carbon (DOC) concentration, suspended particulate matter (SPM), and total iron concentration). The physicochemical fractionation of iron between iron oxyhydroxide and organic colloids showed drastic seasonal variations in the Kalix river, a boreal river that is one of the major contributors of fresh water to the Baltic Sea (Dahlqvist et al., 2007). During the winter, when the top soil is frozen and groundwater is the major source of water in the river, the colloidal iron is dominated by iron oxyhydroxide (Fig. 1a). During the snow melt and following spring flood, colloid-associated iron is mainly complexed to fulvic acid that is carried from mires and eroded from the forest top soils by the snowmelt water (Dahlqvist et al., 2007), which eventually reaches the Baltic Sea.

The general conception is that $\mathrm{Fe}$ is rapidly removed in estuarine systems by aggregation at relative low salinities (e.g. Dai and Martin, 1995; Boyle et al., 1977; Guieu et al., 1996), but exceptions to this have also been observed (Shiller and Boyle, 1991). In estuarine mixing experiments, it was shown that the iron oxyhydroxide colloids from river water aggregate into much larger particles in contact with seawater, while the organic colloidal phase was virtually unaffected (Stolpe and Hassellöv, 2007), similar to the results from previous mixing experiments. Fulvic acids from rivers are less affected by the salinity increase and can therefore be expected to be transported through estuaries and out in the sea. Recent findings from Laglera and van den Berg (2009), suggest that it is possible that terrestrial humic matter may reach the open ocean and account for a significant proportion of the Fe binding ligands.

Measurements of stable Fe isotope fractionation have provided a new tracer, which can give valuable insights into the sources of $\mathrm{Fe}$ and $\mathrm{Fe}$ biogeochemical cycles in marine and terrestrial environment (e.g. Beard et al., 2003; Bergquist and Boyle, 2006; de Jong et al., 2007). In particular, significant fractionation of $\mathrm{Fe}$ isotopes has been demonstrated during oxidation and reduction reactions, suggesting that $\mathrm{Fe}$ isotopes are also useful tracers of $\mathrm{Fe}$ redox cycling (e.g. Staubwasser et al., 2006b; Rouxel et al., 2008). 


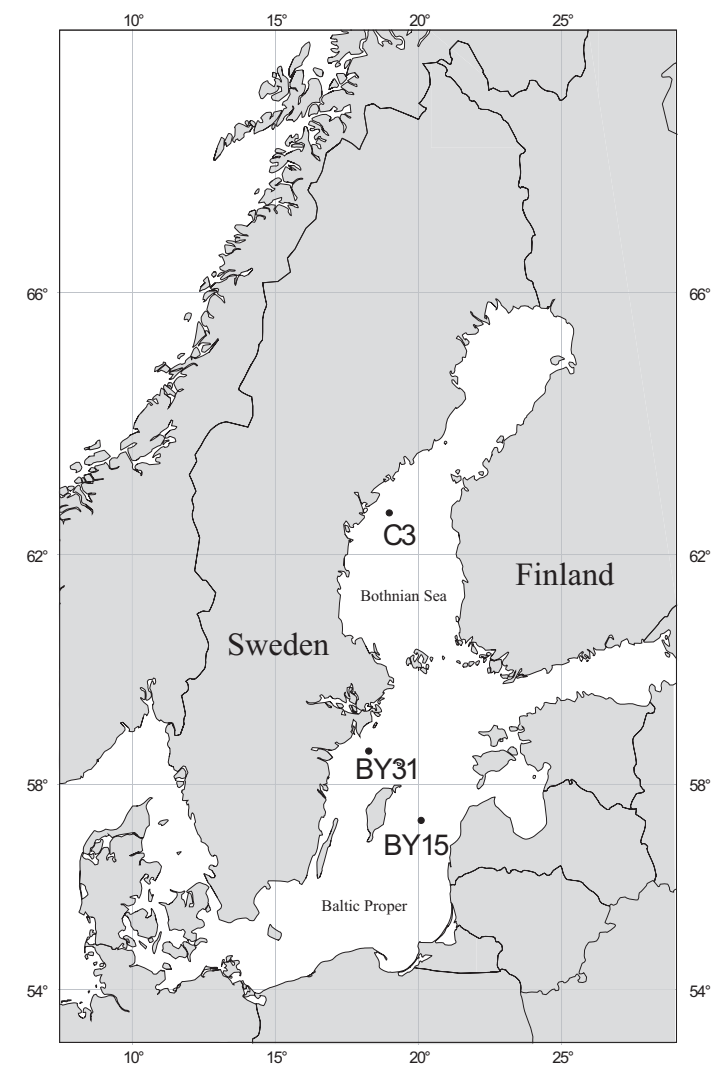

Fig. 2. Map of the sampling stations.

Ingri et al. (2006) suggest to use stable Fe isotopes to roughly identify the iron oxyhydroxide and carbon colloidal phases in freshwater. In this paper we have tested if the model presented by Ingri et al. (2006) is applicable also in the Baltic Sea. Fe isotopes are also used as a tracer for the local sources of Fe.

This study was conducted in the Baltic Sea, which is a semi-enclosed shelf sea and the largest brackish water body in the world. The environment and chemistry of this large estuary is complex due to strong influences from land combined with the occasional Atlantic water salinity pulses through the Danish straights. Generally, the Baltic Sea has a relatively constant halocline at about $70 \mathrm{~m}$ depth (Kullenberg, 1981) and wide areas in the basins are characterized by anoxic deep water that is rich in trace metals and macronutrients (Dyrssen and Kremling, 1990; Brügmann et al., 1992; Pohl and Hennings, 2005; Pohl et al., 2004; Pohl et al., 2006). The Baltic Sea has been given growing attention due to changes in the ecosystem (e.g. Larsson et al., 1985; Bianchi et al., 2000) and recent satellite monitoring studies have shown abundances of intense, yet varying, cyanobacteria blooms (Kahru et al., 2007). Nitrogen fixation by cyanobacterial contributes to $20-40 \%$ of the nitrogen supply to the Baltic Sea (Larsson et al., 2001). The recent increase in cyanobacteria occurrence and den- sity has been attributed to eutrophication (Finni et al., 2001). Alternatively, up-welled phosphorus from deep waters may stimulate growth of cyanobacteria (Kononen et al., 1996; Stal et al., 2003). Iron as a potentially limiting nutrient for cyanobacterial bloom development and nitrogen fixation in the Baltic Sea has been suggested (Stal et al., 1999; Stolte et al., 2006). Nitrogen-fixing cyanobacteria have a Fe demand that is 4-6 times higher than other phytoplankton (Kustka et al., 2002; Sanudo-Wilhelmy et al., 2001) and the development of cyanobacterial blooms may to some degree be regulated by iron bioavailability, as previously suggested for phytoplankton in other coastal regions (Özturk et al., 2002; Hutchins and Bruland, 1998). Further, Ingri et al. (2004) showed that the low molecular weight fraction (LMW, $<5 \mathrm{kDa}$ ) of several trace metals was depleted during a spring bloom in a coastal bay of the Baltic Sea, suggesting a very slow exchange between the particulate, colloidal and the soluble fraction, which also may result in seasonally limited Fe bioavailability. In order to assess the transport and contribution of $\mathrm{Fe}$ from continental sources to the world ocean, one key question is how much Fe will be left in the LMW fraction.

Our objective was to investigate the processes affecting Fe speciation during transport from lower to higher salinity. We studied the physicochemical speciation of Fe over several months of the Nordic spring and summer season in the euphotic zone at three different locations in the Baltic Sea using a wide set of methods, including Fe isotope measurements, to identify Fe sources, Fe carrier phases, and Fe sinks.

\section{Materials and methods}

\subsection{Sampling}

Samples were taken at three locations in the Baltic Sea; the Bothnian Sea (station C3), Landsort Deep (BY31) and Gotland Deep (BY15) (Fig. 2). Water samples for subsequent filtration were taken at $5 \mathrm{~m}$ depth (approximately the middle of the upper mixed layer) from $M / S$ Fyrbyggaren during March to October 2004 at Landsort Deep station. Samples at the Bothnian Sea station were taken from $M / S$ KBV005 from April to September 2006 and at the Gotland Deep station during 2007, samples were taken from $M / S$ Fyrbyggaren, from May to August, also at $5 \mathrm{~m}$ depth. To avoid iron contamination from the hull, a piece of polyethylene (PE) tubing was attached to a flagpole that was pointing out vertically $10 \mathrm{~m}$ from the bow of the ship and lowered to sampling depth. Having this set-up during the ship slow steaming $(<1 \mathrm{kn})$, the opening of the tubing was at least $10 \mathrm{~m}$ away upstream from the hull. Water was pumped through the tubing by a peristaltic pump (Masterflex, Colepalmer) into $25 \mathrm{~L}$ PE containers. Prior to use, all sampling tubing and containers used for metal analysis were acid-cleaned in 5\% vol. $\mathrm{HCl}$ with at least five subsequent washes in purified water 
(Millipore, $>18.2 \mathrm{M} \Omega$ ). Further, water samples from 0.5, 5,10 and $40 \mathrm{~m}$ depth were taken using a Niskin-type water sampler without internal metal parts and equipped with a silicone band closure mechanism (Hydrobios, Kiel, Germany). These samples were analyzed for elemental composition ( $\mathrm{Fe}$ and major seawater elements) without filtration as well as for nutrient and chlorophyll- $a$ sampling (see below). Sediment traps using a design and set-up slightly modified from Larsson et al. (1986) were deployed monthly at $30 \mathrm{~m}$ depth at the Bothnian Sea and Landsort Deep station. Further, DGT (diffusive gradients in thin films) samplers were deployed at $5 \mathrm{~m}$ depth at all stations for periods of up to two months (see below for more detail). At each station, salinity and density data were obtained from CTD profiles.

\subsection{Membrane and cross-flow filtration of surface water samples}

Immediately after collecting water from the flagpole system, membrane filtration $(0.22 \mu \mathrm{m}$ pore size, $142 \mathrm{~mm}$ diameter, Millipore mixed cellulose esters) of the water sample was carried out. The first filter was completely clogged and the filtrate volume was measured. New filters through which only half the clogging volume was pumped were then used to collect the particulate fraction from seawater. The reason for this was to reduce the removal of colloids that is caused by clogging of filters, i.e. colloids will be discriminated in the filtrate when the filter gets clogged (Morrison and Benoit, 2001). Filtrate from several filtrations was collected in $25 \mathrm{~L}$ polyethylene containers from which sub samples for dissolved iron (DFe), Flow Field-Flow Fractionation (FIFFF), and dissolved organic carbon (DOC) analysis were taken. This water was also used for the cross-flow ultrafiltration to determine the soluble iron fraction (see below). The filter material was used for analysis of particulate Fe and iron isotopes. Additionally unfiltered water was sampled for total organic carbon (TOC) and humic substances (HS) analysis. All tubing and containers were acid-cleaned in 5\% vol. $\mathrm{HCl}$ with at least five subsequent washes in MilliQ water (Millipore, $>18.2 \mathrm{M} \Omega$ ) prior and after sampling. Prior to use, filters were washed in 5\% vol. acetic acid, as described by Ödman et al. (1999).

Cross-flow ultrafiltration (CFF) was performed on a Millipore Prep/Scale system (Prep/Scale Spiral Wound TFF-6 module) with a $1 \mathrm{kDa}$ cut-off size using $0.22 \mu \mathrm{m}$ filtrated water collected at five meters depth and was due to practical reasons performed within 5 to $24 \mathrm{~h}$ of the water sample collection. Approximately 12 litres of sample water were used for ultrafiltration. Before the ultrafiltration procedure began, sample water was circulated through the filter to precondition the system. Half a litre of permeate was collected and the system was emptied where upon the actual filtration begun. The concentration factor of the retentate was above 10 to achieve good recovery, as recommended by Larsson et al. (2002). The cross flow ratio (retentate flow/permeate flow) was between 60 and 80. After every ultrafiltration the system was washed with base and acid solutions and Milli-Q water, following a procedure described by Larsson et al. (2002), with the slight modification that both the acid and base solutions had a concentration of $0.01 \mathrm{M}$. CFF permeate and retentate samples were analyzed for their concentrations of Fe, TOC and HS.

\subsection{Diffusive gradients in thin films (DGT)}

DGT samplers (Davison and Zhang, 1994) equipped with Chelex 100 binding gels were manufactured during 2004, and similar to the samplers purchased thereafter from DGT Research Inc (Lancaster, UK). The thickness of the diffusive gels was $0.8 \mathrm{~mm}$. All DGT sampling was carried out in situ, at several depths and DGT samplers were deployed in duplicates. The exposure time for DGT samplers varied from location to location between 14 days and up to two months. A temperature logger (StowAway TidbiT, Onset Computer Corporation) was attached along with the DGT units, logging the temperature every fifth hour. The mean temperature of the deployment period was used to recalculate the diffusion coefficient in the gel. After sampling, DGT devices were disassembled in a class-100 clean air laboratory and the gels

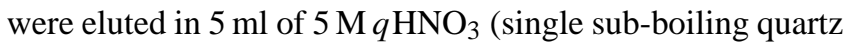
distilled, AR grade nitric acid, Merck). Prior to analysis, water samples were diluted 4-fold with $0.16 \mathrm{Mq} \mathrm{HNO}_{3}$ (of the same quality as for the DGTs) in MilliQ water. The resulting $\mathrm{Fe}$ blank from $\mathrm{HNO}_{3}$ was routinely tested and has not been found to represent a significant contribution to the overall blank levels. Concentrations of Fe collected by the DGT samplers ( $[\mathrm{Fe}]_{\text {DGT }}$ ) were calculated assuming a $0.23 \mathrm{~mm}$ diffusive boundary layer (DBL), which is reasonable to expect in moderate to well mixed waters (Warnken et al., 2006; Garmo et al., 2006). The accumulation area was assumed to be equal to $3.8 \mathrm{~cm}^{2}$ (Warnken et al., 2006). Diffusion coefficients in the gels were supplied by DGT Research Inc (www.DGTresearch.com).

\subsection{Analytical procedures}

\subsubsection{ICPMS analysis for trace element concentrations, including DGT samples}

Analytical work for trace metal analysis of water and DGT samples was performed in class 100 clean room conditions. Concentrations of elements in DGT eluents, unfiltered samples, and $0.22 \mu \mathrm{m}$ and $1 \mathrm{kDa}$ filtrate were measured with an Inductively Coupled Plasma Sector Field Mass Spectrometer (ICP-SFMS, Element, ThermoFinnigan, Bremen, Germany) at ALS Scandinavia (Luleå, Sweden). To reduce seawater matrix interferences samples were diluted four times. For details about the instrument operation, see Rodushkin and Ruth (1997). Matrix induced signal variations and signal instabilities were corrected for using internal 
standards ( $25 \mathrm{ppb}$ In and Ti) added to samples, blanks, and elemental standards. Limit of detection for Fe was typically $\sim 2 \mathrm{nM}$ (100 ppt) for water samples (Rodushkin and Ruth, 1997). Quality control was accomplished by regular analyses of in-house control samples. For six samples that were close to or below the detection limit of the ICP-SFMS, Chemiluminescent Flow Injection Analysis (CL-FIA) with a luminol (5amino-2,3-dihydro-1,4-phthalazine-dione) reagent was used to determine dissolved and soluble $\mathrm{Fe}$ (Bowie et al., 1998). Overlapping measurements from CL-FIA and ICP-SFMS, showed less than $10 \%$ difference.

\subsubsection{Analysis of elements in the particulate phase}

The $0.22 \mu \mathrm{m}$ nitrocellulose filters and sediment trap material were analyzed by ALS Scandinavia $A B$ in Luleå and prepared according to the procedure described by Ödman et al. (1999). Dried filters with particulate material were wet-ashed with concentrated nitric acid in a platinum crucible at $50^{\circ} \mathrm{C}$ and dry-ashed at $550{ }^{\circ} \mathrm{C}$. The residue was weighted, average ashed weight subtracted, giving the ash weight of suspended material. The sample was subsequently digested with an equal amount of dried lithiummetaborate at $1045^{\circ} \mathrm{C}$ for $45 \mathrm{~min}$, giving a bead which was dissolved in $5 \% \mathrm{HNO}_{3}$. Analysis was then performed by atomic emission spectroscopy with inductively coupled plasma as excitation source (ICP-AES) for major elements. Total Fe (TFe) is defined as the sum of particulate $\mathrm{Fe}(\mathrm{PFe}$, total $\mathrm{Fe}$ collected on a filter divided by filtered volume) and dissolved $\mathrm{Fe}$ (DFe).

\subsection{Nutrients, chl- $a$, POC, and DOC}

Nitrogen and phosphorous samples were simultaneously oxidized using a modification of the method of Koroleff (1983). Standard flow injection analysis (QuickChem ${ }^{\circledR} 8000$ method 31-115-01-3-A, 31-107-06-1-A, Lachat Instruments) was used to measure dissolved inorganic phosphorous (DIP) and dissolved inorganic nitrogen (DIN; $\left(\mathrm{NH}_{4}^{+}+\mathrm{NO}_{2}^{-}+\mathrm{NO}_{3}^{-}\right)$). For chlorophyll- $a$ (chl- $a$ ) determinations, $2 \mathrm{~L}$ of seawater were filtered on $47 \mathrm{~mm}$ Whatman GF/F filters, which were stored frozen at $-20^{\circ} \mathrm{C}$ and extracted by acetone before spectrophotometric measurements at $664 \mathrm{nmol} \mathrm{L}^{-1}$ (SS 02 $8146)$. At Landsort Deep and Gotland Deep, this was done for samples from discrete depths, at the Bothnian Sea station integrated samples of the upper $10 \mathrm{~m}$ were taken using a $10 \mathrm{~m}$ long hose that was lowered vertically into the water. The upper end of the hose was then closed and the hose was emptied into a carboy from which water were taken to chl- $a$ analysis. Total organic carbon (TOC) content was analysed at Umeå Marine Science Centre (Norrbyn, Sweden) using hightemperature catalytic oxidation instrument (Shimadzu TOC 5000). The analytical protocols for dissolved organic carbon (DOC) samples have been described in detail by Gustafsson et al. (2001). The DOC samples were acidified with $200 \mu \mathrm{L}$ of $1.2 \mathrm{M} \mathrm{HCl}$ to remove inorganic carbon and were quanti- fied with a high-temperature catalytic oxidation instrument (Shimadzu TOC 5000).

\subsubsection{Combined flow field-flow fractionation ICPMS analysis}

Flow field-flow fractionation (FIFFF) is a chromatographylike elution technique for the characterization of colloids, where the retention of colloids depends on their ability to diffuse against a flow of liquid in an open channel. The diffusion coefficient, and thereby the hydrodynamic diameter, can be calculated from the retention time (Giddings, 1993). Samples were analyzed using on-line coupling of FIFFF to UV-absorbance and fluorescence detectors, as well as to inductively coupled plasma mass spectrometry (for simplicity hereafter abbreviated as FFF-ICPMS) as described previously (Hassellöv et al., 1999; Stolpe et al., 2005). By this combination of techniques, the continuous colloidal size distribution of chromophores, fluorophores and different elements can be determined.

\subsubsection{Iron isotope measurements}

Suspended matter from clogged $0.22 \mu \mathrm{m}$ nitrocellulose filters collected at the Bothnian Sea and Landsort Deep stations ( $5 \mathrm{~m}$ depth) and sediment trap material from the Landsort Deep station were analysed with regard to $\mathrm{Fe}$ isotopic composition. Fe-isotope ratio measurements were performed with a double focusing high resolution MC-ICPMS instrument (Neptune, Thermo Finnigan, Germany) with detailed procedures described by Ingri et al. (2006) and Malinovsky et al. (2003). Results are presented using the $\delta$-notation, defined as

$\delta^{56} \mathrm{Fe}=\left[\left({ }^{56} \mathrm{Fe} /{ }^{54} \mathrm{Fe}\right)_{\text {sample }} /\left({ }^{56} \mathrm{Fe} /{ }^{54} \mathrm{Fe}\right)_{\text {standard }}-1\right] \cdot 1000$

where the $\left({ }^{56} \mathrm{Fe} /{ }^{54} \mathrm{Fe}\right)_{\text {standard }}$ is the ratio for IRMM-014, corrected for instrumental mass discrimination using Ni. Similar notations were also used for the ${ }^{57} \mathrm{Fe} /{ }^{54} \mathrm{Fe}$ and ${ }^{57} \mathrm{Fe} /{ }^{56} \mathrm{Fe}$ ratios. The external reproducibility expressed as one standard deviation is generally better than $50 \mathrm{ppm}$. Therefore, changes in d-values at the $0.1 \%$ o level can be readily distinguished (Malinovsky et al., 2003).

\subsubsection{Analysis of humic substances}

To measure the concentration of humic substances (HS), a Jasco FP-777 spectroflourometer with a $1 \mathrm{~cm}$ quartz-cell was used. Fluorescence intensity was read at an emission at $350 \mathrm{~nm}$ from excitation at $450 \mathrm{~nm}$ and was then converted to HS concentration by comparison with a standard curve of Quinine Sulphate. The samples were collected in clean amber glass bottles and kept refrigerated before reading. The flourometer cell was rinsed with deionised water and sample before every reading. The molar extinction coefficient at $280 \mathrm{~nm}(\varepsilon 280)$ was derived from normalizing the absorbance at $280 \mathrm{~nm}$ (A280) to the TOC content of the sample. This 
Table 1. Iron concentration at $5 \mathrm{~m}$ depth in different fractions at the three studied stations in the Baltic Sea. All Fe concentrations are given in $\mathrm{nM}$. The \pm notation indicate the standard deviation for mean values, for max and minimum values, \pm indicate the precision of the measurement.

\begin{tabular}{llll}
\hline Station & $\begin{array}{l}\text { Bothnian Sea (C3) } \\
n=8\end{array}$ & $\begin{array}{l}\text { Landsort Deep (BY31) } \\
n=15\end{array}$ & $\begin{array}{l}\text { Gotland Deep (BY15) } \\
n=5\end{array}$ \\
\hline Mean Salinity & $4.69 \pm 0.23$ & $6.29 \pm 0.30$ & $7.03 \pm 0.10$ \\
Mean TFe & $114 \pm 87$ & $44 \pm 30$ & $15 \pm 2.5$ \\
Max TFe & $309 \pm 11$ & $108 \pm 1$ & $24 \pm 0.3$ \\
Mean DFe & $21.3 \pm 10$ & $7.0 \pm 3.8$ & $3.8 \pm 1.8$ \\
Max DFe & $32.4 \pm 2.5$ & $13.7 \pm 0.41$ & $7.0 \pm 4.0$ \\
Min DFe & $6.0 \pm 0.09$ & $1.9 \pm 0.11$ & $2.7 \pm 0.17$ \\
Mean SFe & $6.2 \pm 2.5$ & $5.9 \pm 3.0$ & $3.2 \pm 0.96$ \\
Max SFe & $10 \pm 1.8$ & $13.1 \pm 0.78$ & $4.4 \pm 1.8$ \\
Min SFe & $3.2 \pm 0.18$ & $2.7 \pm 0.19$ & $2.1 \pm 0.12$ \\
DGT (top 40 m & 1.3 in spring, 0.9 & 0.35 on average, but no & 0.44 May-June \\
average) & during summer & clear tend during the year. & 0.26 July-August \\
\hline
\end{tabular}

Table 2. Different fractions of Fe expressed as percentage of total $\mathrm{Fe}(\mathrm{TFe})$.

\begin{tabular}{|c|c|c|c|}
\hline & $\mathrm{DFe}(<0.22 \mu \mathrm{m})$ & $\mathrm{SFe}(<1 \mathrm{kDa})$ & $\mathrm{CFe}(1 \mathrm{kDa}-0.22 \mu \mathrm{m})$ \\
\hline Bothnian Sea (C3) & $\begin{array}{l}\text { 9\% of TFe in April, } \\
20-30 \% \text { May-August }\end{array}$ & $\begin{array}{l}3.2 \% \text { of TFe in April, } \\
6.5-13 \% \text { May-August }\end{array}$ & $\begin{array}{l}5.8 \% \text { of TFe in April, } \\
16-20 \% \text {, May-August }\end{array}$ \\
\hline Landsort Deep (BY31) & $\begin{array}{l}27 \% \text { of TFe in March } 10-22 \% \\
\text { during April-May, varying during } \\
\text { June-October, showing a } \\
\text { max. of } 50 \%\end{array}$ & $\begin{array}{l}\text { Initially } 15 \% \text { of TFe in March. } \\
5-10 \% \text { during spring and a few } \\
\text { high numbers June-October } \\
\text { (max. } \sim 50 \% \text { ) }\end{array}$ & $\begin{array}{l}12.6 \% \text { of TFe in March, } \\
3.6-10 \% \text { during spring, } \\
0-8 \% \text { June-October }\end{array}$ \\
\hline Gotland Deep (BY15) & $23-54 \%$ of $\mathrm{TFe}$ & $18-41 \%$ of $\mathrm{TFe}$ & $5-10 \%$ of $\mathrm{TFe}$ \\
\hline
\end{tabular}

parameter represents the $\pi-\pi^{*}$ transition of aromatic carbon atoms of the organic matter (Gauthier et al., 1987; Chin et al., 1994). Absorbance measurements ( $2 \mathrm{~nm}$ bandwidth) were carried out on a UV/VIS absorption spectrophotometer having two parallel light paths.

\section{Results}

An overview of Fe concentrations in different fractions, and average salinities at the three stations is presented in Table 1 . A general trend is that while salinity increases from north (Bothnia Sea) to south (Baltic Proper, station BY15), total and dissolved Fe clearly decreases. In Table 2 the percentage of different fractions (as \% of TFe) is given. From this data, it is clear that the station of lowest salinity (Bothnian Sea) has a higher proportional amount of $\mathrm{Fe}$ in the colloidal pool, and less in the dissolved compared to the other two. The concentrations of the different fractions at the these stations are changing significantly during the measured periods, more details are given below.

\subsection{Bothnian Sea (C3)}

\subsubsection{Biogeochemical framework}

At the Bothnian Sea station, a weak stratification was developed in May, which became stronger towards the end of sampling period (Fig. 3). A very weak permanent halocline was observed at about 50-70 m depth during the course of the study (Fig. 3), which is quite typical for the Bothnian Sea (Kullenberg, 1981). A minimum in salinity was observed on 23 May, where the water column down to $12 \mathrm{~m}$ was below 4.4. A chl- $a$ maximum of $6.7 \mu \mathrm{g} / \mathrm{L}$ (integrated value for the upper $10 \mathrm{~m}$ ) was measured in April, and after that date the concentration was gradually deceasing down to $1.3 \mu \mathrm{g} / \mathrm{L}$ in late June. Then the amount of chl- $a$ was \pm stable above $1 \mu \mathrm{g} / \mathrm{L}$ until September. TOC was rather stable around $350 \mu \mathrm{M}$, where the colloidal fraction comprised about $130 \mu \mathrm{M}$. Both $\varepsilon 280$ and HS (Table 3) showed a small increase from April to May and were then continuously decreased until September. 
Table 3. Humic substances (HS; $\mu \mathrm{g} / \mathrm{L}$, QSE), $\varepsilon 280$ and total organic carbon (TOC; $\mu \mathrm{M})$ in different size fractions at the Bothnian Sea (C3), Landsort Deep (BY31) and Gotland Deep (BY15).

\begin{tabular}{|c|c|c|c|c|c|c|c|c|c|c|}
\hline Station & Date & $\begin{array}{r}\text { HS } \\
\text { Total }\end{array}$ & $\begin{array}{r}\text { HS } \\
<0.22 \mu \mathrm{m}\end{array}$ & $\begin{array}{r}\mathrm{HS} \\
<1 \mathrm{kDa}\end{array}$ & $\begin{array}{l}\varepsilon 280 \\
\text { Total }\end{array}$ & $\begin{array}{r}\varepsilon 280 \\
<0.22 \mu \mathrm{m}\end{array}$ & $\begin{array}{r}\varepsilon 280 \\
<1 \mathrm{kDa}\end{array}$ & $\begin{array}{l}\text { TOC } \\
\text { Total }\end{array}$ & $\begin{array}{r}\text { TOC } \\
<0.22 \mu \mathrm{m}\end{array}$ & $\begin{array}{r}\text { TOC } \\
<1 \mathrm{kDa}\end{array}$ \\
\hline C3 & 2006-04-25 & 12.50 & & 8.30 & 161.17 & & 173.75 & 325.00 & 308.33 & 216.67 \\
\hline $\mathrm{C} 3$ & 2006-05-23 & 14.50 & 14.50 & 8.70 & 200.51 & 189.47 & 158.24 & 337.50 & 316.67 & 204.17 \\
\hline $\mathrm{C} 3$ & 2006-06-06 & 13.30 & 13.70 & & 153.73 & 142.35 & 123.79 & 329.17 & 325.00 & 241.67 \\
\hline C3 & 2006-06-27 & 12.70 & 13.20 & 8.60 & 137.86 & 139.79 & 73.79 & 379.17 & 333.33 & 283.33 \\
\hline $\mathrm{C} 3$ & 2006-07-19 & 12.00 & 12.20 & 7.40 & 141.59 & 138.59 & 57.65 & 341.67 & 325.00 & 208.33 \\
\hline $\mathrm{C} 3$ & 2006-08-01 & 10.90 & 11.30 & 7.40 & 130.58 & 121.44 & 87.04 & 362.50 & 345.83 & 233.33 \\
\hline $\mathrm{C} 3$ & 2006-08-15 & 10.30 & 10.50 & 7.10 & 113.74 & 123.85 & 95.47 & 366.67 & 312.50 & 216.67 \\
\hline $\mathrm{C} 3$ & 2006-09-03 & 9.70 & 9.70 & 6.60 & 128.12 & 112.10 & 78.53 & 291.67 & 312.50 & 216.67 \\
\hline BY31 & 2004-03-10 & 5.93 & 5.98 & 4.69 & 132.47 & 125.90 & 110.79 & 337.19 & 345.52 & 278.91 \\
\hline BY31 & 2004-03-24 & 5.53 & & 4.29 & 138.59 & & 121.35 & 324.70 & & \\
\hline BY31 & 2004-03-31 & 5.47 & 5.60 & 4.05 & 127.46 & 124.50 & & 353.84 & 341.35 & 262.26 \\
\hline BY31 & 2004-04-06 & 5.78 & 5.73 & 4.32 & 142.87 & 141.25 & 113.54 & 316.38 & 312.21 & 278.91 \\
\hline BY31 & 2004-04-14 & 5.53 & 5.52 & 4.30 & 131.52 & 133.19 & 113.07 & 333.03 & 328.87 & 274.75 \\
\hline BY31 & 2004-04-21 & 5.36 & 5.19 & 4.14 & 128.61 & 124.50 & 111.65 & 341.35 & 341.35 & 291.40 \\
\hline BY31 & 2004-05-04 & 5.27 & 4.93 & 3.90 & 125.48 & 121.51 & 116.51 & 353.84 & 341.35 & 287.24 \\
\hline BY31 & 2004-06-02 & 4.99 & 4.76 & 3.99 & 134.29 & 117.71 & 121.81 & 345.52 & 374.66 & 274.75 \\
\hline BY31 & 2004-06-16 & 4.68 & 4.69 & 3.63 & 151.30 & 144.46 & 115.78 & 316.38 & 303.89 & 253.93 \\
\hline BY31 & 2004-06-30 & 5.16 & 5.06 & 3.96 & 145.19 & 132.72 & 141.42 & 316.38 & 316.38 & 258.10 \\
\hline BY31 & 2004-07-15 & 5.27 & 5.04 & 3.95 & 163.99 & 147.08 & 134.16 & 312.21 & 316.38 & 253.93 \\
\hline BY31 & 2004-07-26 & 4.76 & 4.72 & 3.72 & 164.26 & 140.33 & 133.25 & 308.05 & 324.70 & 266.42 \\
\hline BY31 & 2004-08-11 & 4.46 & 4.18 & 3.31 & 148.40 & 128.22 & 123.26 & 312.21 & 328.87 & 253.93 \\
\hline BY31 & 2004-09-08 & 5.05 & 4.93 & 3.87 & 127.14 & 116.85 & 97.04 & 341.35 & 358.01 & 316.38 \\
\hline BY31 & 2004-10-06 & 5.10 & 5.13 & 4.07 & 147.92 & 148.02 & 121.89 & 308.05 & 283.07 & 262.26 \\
\hline BY15 & 2007-05-24 & & & & & & & 383.33 & 354.17 & 229.17 \\
\hline BY15 & 2007-06-20 & & & & & & & 466.67 & 337.50 & 270.83 \\
\hline BY15 & $2007-07-20$ & & & & & & & 358.33 & 362.50 & 287.50 \\
\hline BY15 & 2007-08-02 & & & & & & & 437.50 & 354.17 & 275.00 \\
\hline BY15 & 2007-08-14 & & & & & & & 341.67 & 325.00 & 208.33 \\
\hline
\end{tabular}

\subsubsection{Iron speciation}

During the whole measured period, the iron in surface waters of the Bothnian Sea station was dominated by the particulate fraction; DFe initially comprised $9 \%$ of $\mathrm{TFe}$ and was increasing its proportion towards the summer (Table 2). TFe decreased $89 \%$ from April to mid August (309 nM to a minimum of $34 \mathrm{nM}$ ), followed by a slight increase in early September (Fig. 4a). DFe concentration were about $30 \mathrm{nM}$ in April/May and decreased down to $6 \mathrm{nM}$ in September, which is a decrease of about $80 \%$.

When minimum salinity was observed on 23 May (4.3), the highest levels of unfiltered $\mathrm{Fe}$ and $\mathrm{P}$ were measured, and at the same time a minima of major elements like sodium $(\mathrm{Na})$, calcium $(\mathrm{Ca})$ and magnesium $(\mathrm{Mg})$ were observed (Fig. 5). After this date, salinity was continuously increasing along with the major elements, while Fe, Al, P and Mn decreased. This is reflected in a clear negative correlation between salinity and TFe $\left(R^{2}=0.83\right)$, if the value from April is excluded (Fig. 4b). A clear positive correlation was also observed between unfiltered $\mathrm{Fe}, \varepsilon 280$ and humic substances. Both the total and the dissolved Fe showed this correlation. PFe had a clear correlation to chl- $a$ during the whole sampling period $\left(r^{2}=0.98\right.$, Fig. $\left.4 c\right)$. The filtered fractions also showed a distinct decline (Fig. 4d), where $<0.22 \mu \mathrm{m}$ (DFe) decreased $69 \%(28 \mathrm{nM}$ to $8.7 \mathrm{nM})$ and $<1 \mathrm{kDa}(\mathrm{SFe}) 43 \%$ from April to August ( $10 \mathrm{nM}$ to $3.2 \mathrm{nM}$ ). Colloidal bound Fe concentrations $(\mathrm{CFe})$ were clearly decreasing during the sampled period which is indicated by the decreased differences between SFe and DFe fractions (Fig. 4d). The amount of CFe was higher than the Landsort Deep and Gotland Deep stations, and also the proportion CFe of TFe (Table 2).

Sediment trap data (30m depth, data not shown), indicate that there was a correlation in sedimentation between of $\mathrm{C}$, $\mathrm{N}$ and $\mathrm{P}$ and $\mathrm{Fe}$. 

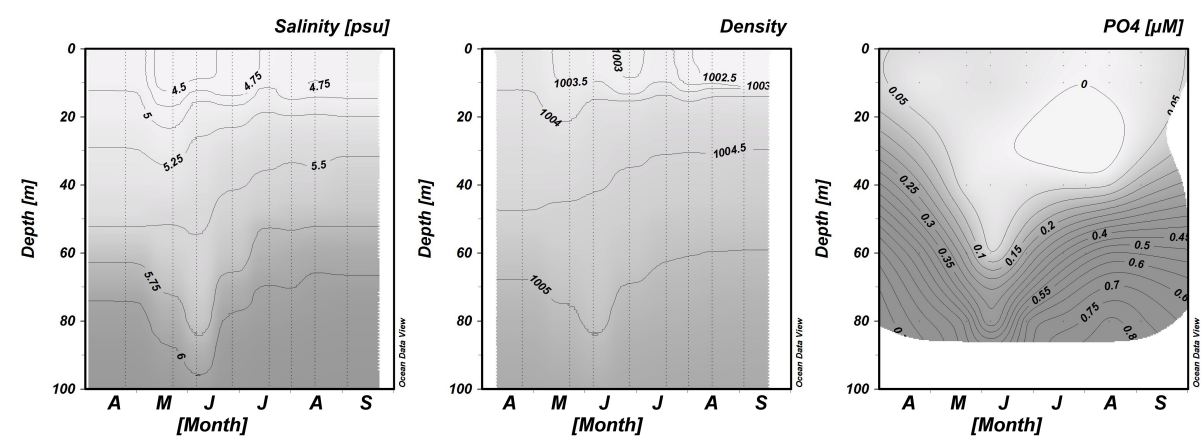

Fig. 3. Time series of salinity, density and $\mathrm{PO}_{4}^{2-}$ in the upper $100 \mathrm{~m}$ at the Bothnian Sea station (C3) during 2006. This figure was prepared with Ocean Data View using DIVA gridding.
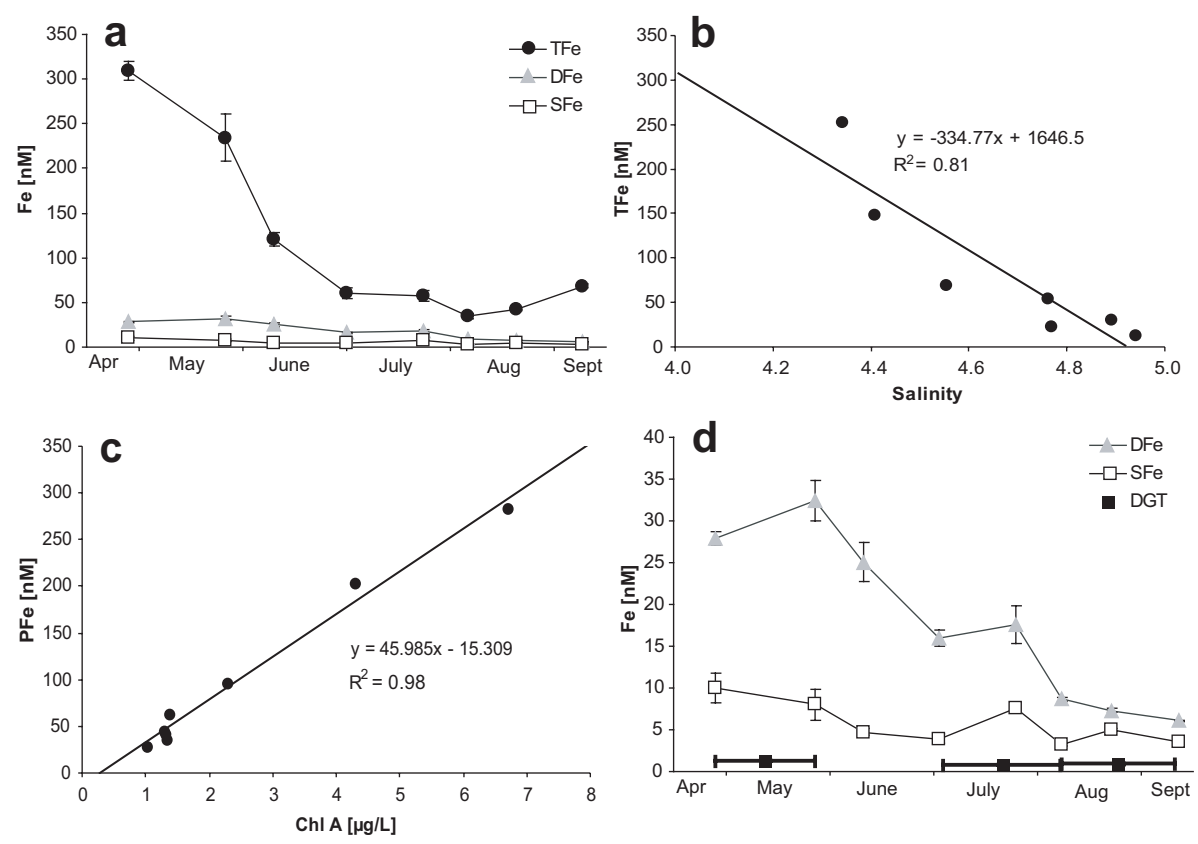

Fig. 4. Bothnian Sea 2006. Concentrations of TFe (total Fe), DFe $(<0.22 \mu \mathrm{m})$ and $\mathrm{SFe}(<1 \mathrm{kDa})$ (a). Regression between unfiltered $\mathrm{Fe}$ and Salinity at $5 \mathrm{~m}$ depth, May to September (b). Regression between chlorophyll- $a$ and suspended Fe (PFe) (c). Concentrations of $\mathrm{DFe}(<0.22 \mu \mathrm{m}), \mathrm{SFe}(>1 \mathrm{kDa})$ and DGT-labile Fe ([Fe $\left.]_{\mathrm{DGT}}\right)$ (d). For DGT measurements, the vertical lines indicate the time period for the measurement, and the filled square represent the mid-date.
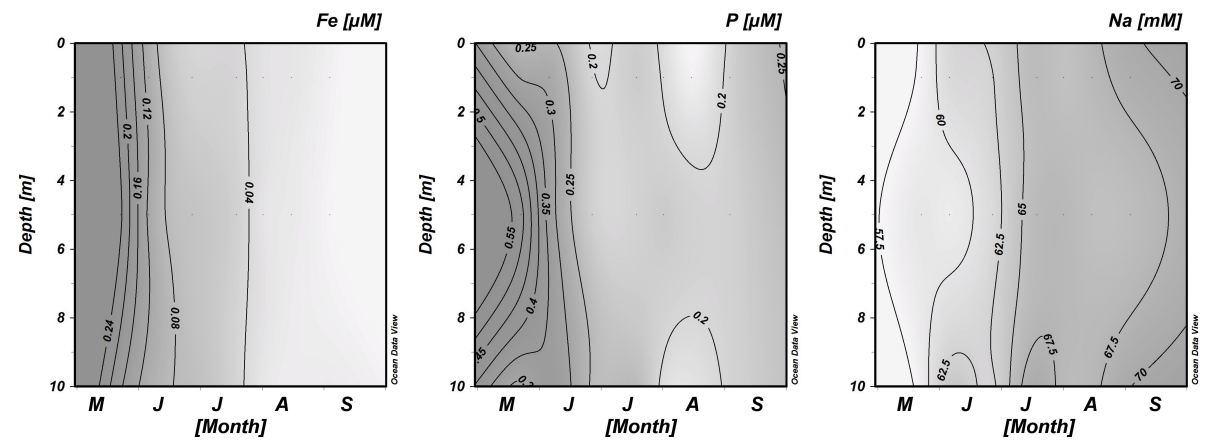

Fig. 5. Variations of total Fe (unfiltered samples), phosphorus (P) and sodium (Na) for the uppermost $10 \mathrm{~m}$ at the Bothnian Sea station 2006. Date format is decimal year. This figure was prepared with Ocean Data View using DIVA gridding. for samples taken at $0.5,5$ and $10 \mathrm{~m}$ depth. 
Table 4. Fe isotopic composition $\left(\delta^{56} \mathrm{Fe}\right)$ of suspended matter $(\mathrm{PFe})$ at $5 \mathrm{~m}$ depth at $\mathrm{C} 3$ (Bothnian Sea) and BY31 (Landsort Deep, Baltic Proper) and sediment trap collected material at BY31. "2STD" denote instrumental precision $\pm 2 \mathrm{STD}$ of the mean. Fe/Ti and Fe/Al denote the ratios between these elements in the samples $(\mathrm{g} / \mathrm{g})$.

\begin{tabular}{lllrrrr}
\hline Station & Sample & Date & $\delta^{56}$ Fe [\%o] & 2STD & Fe/Ti & Fe/Al \\
\hline C3 & PFe & $2006-04-25$ & 0.12 & 0.03 & 28.424 & 1.058 \\
C3 & PFe & $2006-05-23$ & 0.07 & 0.01 & 24.416 & 1.117 \\
C3 & PFe & $2006-06-06$ & 0.14 & 0.03 & 29.901 & 1.186 \\
C3 & PFe & $2006-06-27$ & 0.20 & 0.03 & 35.308 & 1.447 \\
C3 & PFe & $2006-07-19$ & 0.10 & 0.02 & 23.391 & 0.485 \\
C3 & PFe & $2006-08-01$ & 0.16 & 0.01 & 28.271 & 1.211 \\
BY31 & PFe & $2004-03-31$ & -0.08 & 0.04 & 16.976 & 0.690 \\
BY31 & PFe & $2004-04-06$ & -0.04 & 0.04 & 16.416 & 0.599 \\
BY31 & PFe & $2004-04-14$ & 0.05 & 0.04 & 17.540 & 0.633 \\
BY31 & PFe & $2004-04-21$ & 0.25 & 0.04 & 17.473 & 0.661 \\
BY31 & PFe & $2004-05-04$ & 0.24 & 0.04 & 18.182 & 0.851 \\
BY31 & PFe & $2004-06-02$ & 0.26 & 0.04 & 15.607 & 0.612 \\
BY31 & PFe & $2004-06-30$ & 0.20 & 0.04 & 22.692 & 0.843 \\
BY31 & PFe & $2004-07-15$ & 0.28 & 0.04 & 21.442 & 0.859 \\
BY31 & PFe & $2004-10-06$ & 0.00 & 0.04 & 19.345 & 0.747 \\
BY31 & Sediment trap & $2004-04-12$ & -0.08 & 0.03 & 11.463 & 0.667 \\
BY31 & Sediment trap & $2004-04-27$ & -0.10 & 0.01 & 9.741 & 0.454 \\
BY31 & Sediment trap & $2004-06-09$ & -0.18 & 0.03 & 11.682 & 0.601 \\
BY31 & Sediment trap & $2004-06-23$ & -0.08 & 0.01 & 11.538 & 0.607 \\
BY31 & Sediment trap & $2004-07-07$ & -0.19 & 0.04 & 11.634 & 0.560 \\
BY31 & Sediment trap & $2004-07-20$ & -0.24 & 0.03 & 14.191 & 0.810 \\
BY31 & Sediment trap & $2004-08-03$ & -0.15 & 0.01 & 18.097 & 0.893 \\
\hline
\end{tabular}

\subsubsection{Isotopic signatures}

Isotope signatures in PFe were throughout the measured period positive, i.e. enriched in heavy isotopes relative the IRMM-014 standard (Fig. 6a and Table 4). The lowest $\delta^{56} \mathrm{Fe}$ was measured from a sample collected 23 May $(0.07 \%$ ) and the highest $(0.20 \%$ ) was measured 30 June. The Fe/Ti $(\mathrm{g} / \mathrm{g})$ ratio was above 23 during the whole measured period (Table 4), which may be compared to the average crust ratio of 10.2 (Rudnick et al., 2003).

\subsection{Landsort Deep (BY31)}

\subsubsection{Biogeochemical framework}

During the whole sampling period, the water column down to about $60 \mathrm{~m}$ depth was oxygenated close to saturation, which also was the current level of the halocline (Fig. 7). Salinity decreased by $\sim 0.8$ units from March to mid August in the integrated upper $10 \mathrm{~m}$ of the water column, but was much more stable at $40 \mathrm{~m}$ depth (Fig. 7). From rather well mixed water above the halocline in March, conditions changed to a more stratified situation in June to September, where the upper mixed layer was about 10-20 m (Fig. 7). Chl- $a$ demonstrated a peak in the upper $10 \mathrm{~m}$ on 24 March, reflecting the spring bloom (Fig. 7). This peak was followed by a peak during mid-April and thereafter several small peaks,

Phosphate had similar concentrations from the surface down to $40 \mathrm{~m}$ in early March $(\sim 800 \mathrm{nM})$ but then decreased drastically at $0-10 \mathrm{~m}$ during spring and summer (Fig. 7). The concentration at $40 \mathrm{~m}$ remained high $(500-800 \mathrm{nM})$ throughout the sampled period. TOC did not show great variations during the season. Concentrations were between 310 and $350 \mu \mathrm{M}$, with a trend of somewhat lower concentrations during June-August. Colloidal organic carbon concentrations were relatively stable, with an average of $90 \mu \mathrm{M}$.

\subsubsection{Iron speciation}

High initial concentrations of Fe were observed (Fig. 8a), a similar pattern as for the Bothnian Sea station. Around $80 \%$ of $\mathrm{TFe}$ were removed after the spring bloom. A clear correlation between chl- $a$ and $\mathrm{PFe}$ was observed for the first 5 sampling occasions (Fig. 8b). The decreases of the $\mathrm{DFe}$ and $\mathrm{SFe}$ fractions from 10 March to 4 May were of the same magnitude (69\% and 64\% respectively; Fig. 8c). The decline in DFe $(13.7 \mathrm{nM}-4.3 \mathrm{nM})$ was similar to what was measured at Bothnian Sea, but the changes in the $\mathrm{SFe}$ fraction $(7.4 \mathrm{nM}-2.7 \mathrm{nM})$ indicate a clear difference in colloidal speciation. Even though the DFe concentration at the 


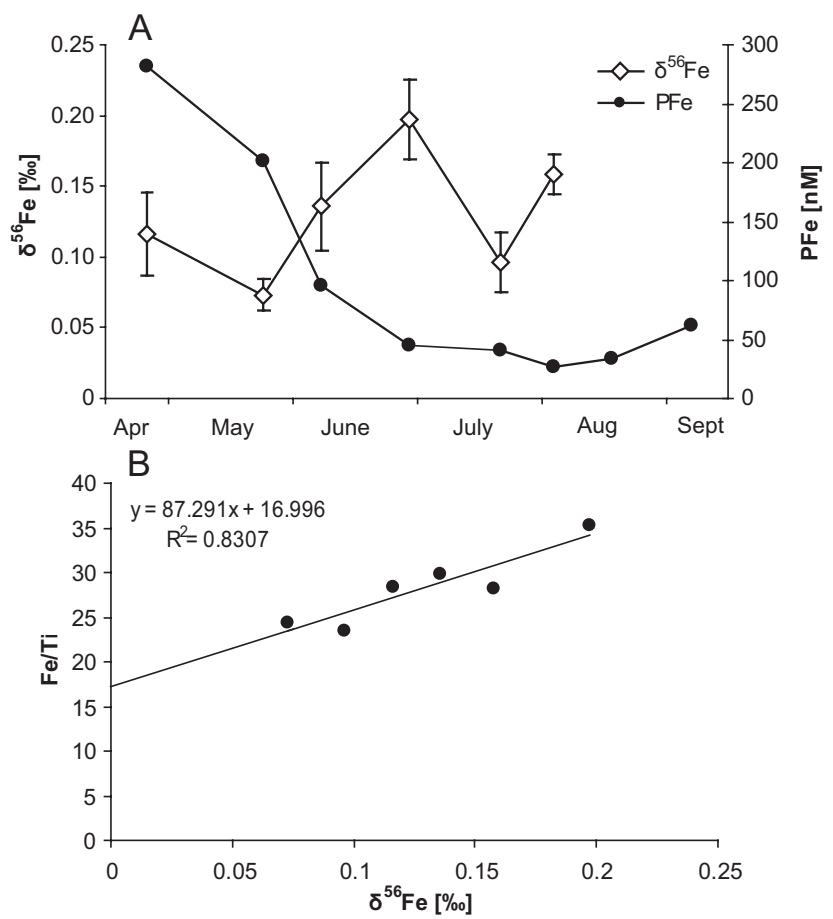

Fig. 6. PFe in the Bothnian Sea station 2006 (filled dots) and Fe isotopic signatures of the suspended matter (open diamonds) (a). Error bars indicate instrumental precision \pm 2 STD of the mean. Regression between $\mathrm{Fe}$ isotopic signature and $\mathrm{Fe} / \mathrm{Ti}$ ratios of the suspended matter (PFe) (b).

Landsort Deep station was less than one third of what was measured at Bothnian Sea (on average $7.0 \mathrm{nM}$ vs. $21.3 \mathrm{nM}$ ), the $\mathrm{SFe}$ concentrations were almost similar. Data on SFe are partly missing from the summer, but the numbers we have suggest that the $\mathrm{CFe}$ pool was almost depleted from May on. There was no correlation between TFe and salinity at Landsort Deep. A peak of DFe (and SFe) was observed at 26 July (Fig. 8c), where the concentration was elevated from 4 to $14 \mathrm{nM}$ in one month time. This peak correlates with an elevated level of $\varepsilon 280$ during the summer, while no other measured parameter showed this drastic change.

The vertical flux of $\mathrm{Fe}$ to the sediment traps at were decreasing from 131 in April to $6.9 \mu$ moles $/$ day $/ \mathrm{m}^{2}$ in August (Fig. 10), which means that the sedimenting Fe has similar temporal trend as the $\mathrm{PFe}$ at $5 \mathrm{~m}$ depth. While the amount of $\mathrm{PFe}$ at $5 \mathrm{~m}$ depth is decreasing during the summer, the amount of sedimenting $\mathrm{Fe}$ changes to a lesser extent from May to August (relatively stable around $50 \mu$ moles $/$ day $/ \mathrm{m}^{2}$ ).

\subsubsection{Isotopic signature of $\mathrm{PFe}$ and sediment trap material}

The isotopic signature of $\mathrm{PFe}$ was changing during the spring bloom, from -0.08 to $+0.25 \%$ in only 2 weeks (Fig. $11 \mathrm{a}$, Table 4). During the summer, the $\delta^{56} \mathrm{Fe}$ was positive at all
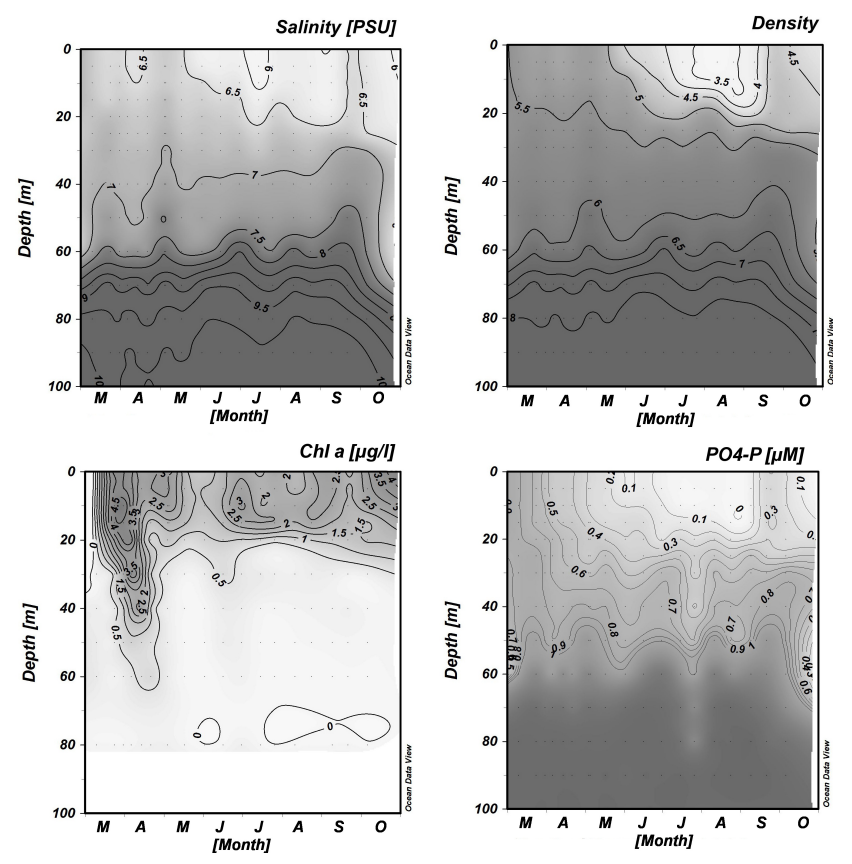

Fig. 7. Time series of salinity, density, chl- $a$ and $\mathrm{PO}_{4}^{2-}$ in the upper $100 \mathrm{~m}$ at the Landsort Deep station (BY31) during 2004. This figure was prepared with Ocean Data View using DIVA gridding.

measured occasions. At 6 October, the $\delta^{56} \mathrm{Fe}$ decreased back to zero. Fe isotopic signatures of the sedimenting material were at all measured occasions negative (Fig. 11c) and show a trend of more negative values towards the summer (with the exception of 23 June). No linear correlation between $\mathrm{Fe} / \mathrm{Ti}$ and the $\delta^{56} \mathrm{Fe}$ value could be observed (Fig. 11d).

\subsection{Gotland Deep (BY15)}

\subsubsection{Biogeochemical framework}

At $5 \mathrm{~m}$ depth, salinity was around 7, but showed a slightly lower value in the end of June and a maximum in mid $\mathrm{Au}-$ gust. Chl- $a$ levels were increasing throughout the whole sampling period to reach the highest value of $4.13 \mu \mathrm{g} / \mathrm{L}$ in mid August. Surface temperatures increased from 15.4 to $19.7^{\circ} \mathrm{C}$ during the sampled period. Similar to the Landsort Deep station, the Gotland Deep is characterized by a $\sim 60 \mathrm{~m}$ deep layer of low salinity $(S<7.5)$ surface water and an intermediate boundary water layer $(S=7.5-11)$ between 60-100 m overlaying more saline deep water. A differentiation between oxygenated surface water and oxygen-depleted deeper water, separated by a redox-cline at $\sim 80 \mathrm{~m}$, was present throughout the sampling period (Fig. 12). Salinity and temperature indicate a mixed layer depth of 16 to $21 \mathrm{~m}$ (Fig. 12). TOC concentrations were stable around $400 \mu \mathrm{M}$, having a colloidal fraction that varied from 70 to $120 \mu \mathrm{M}$ during the summer. 

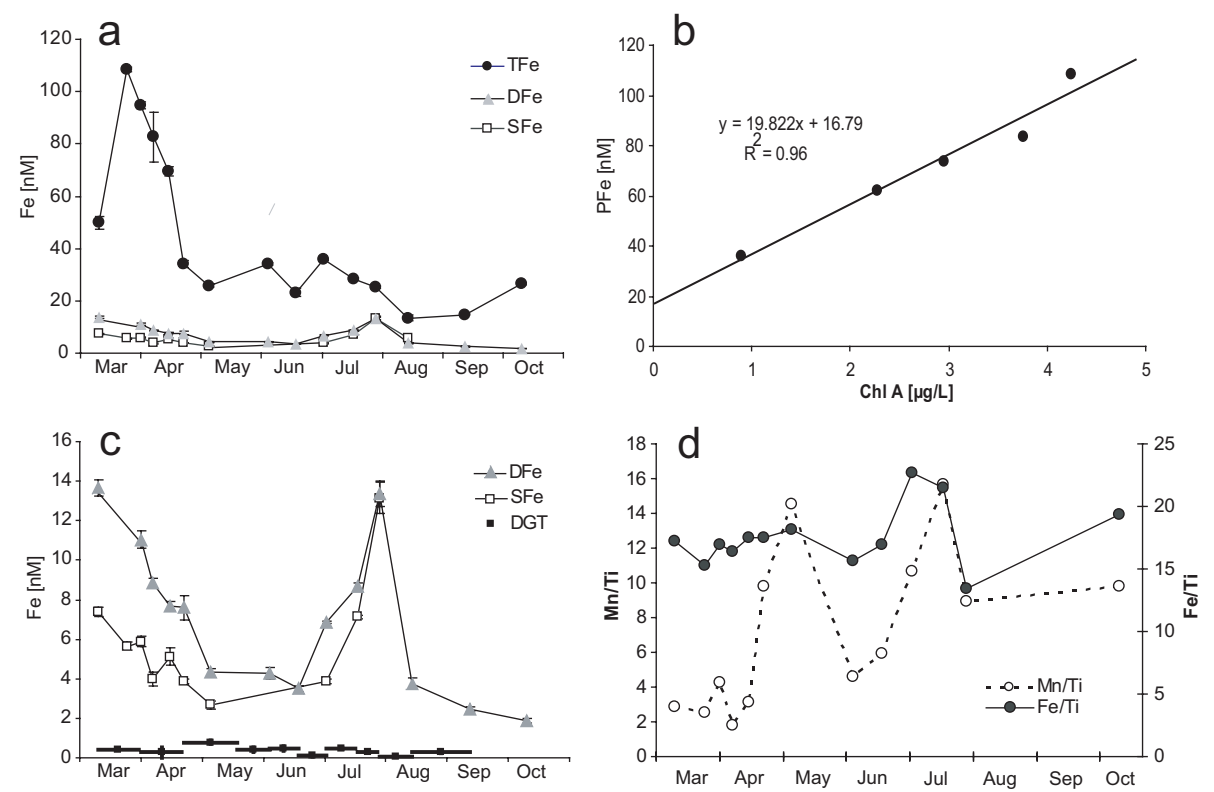

Fig. 8. Landsort Deep station (BY31) 2004. Concentrations TFe (total Fe), DFe $(<0.22 \mu \mathrm{m})$ and SFe ( $<1 \mathrm{kDa})$ (a). Regression between unfiltered Fe and Salinity at $5 \mathrm{~m}$ depth, the five first sampling occasions (b). Concentrations of DFe $(<0.22 \mu \mathrm{m}), \mathrm{SFe}(>1 \mathrm{kDa})$ and DGTlabile $\mathrm{Fe}\left([\mathrm{Fe}]_{\mathrm{DGT}}\right)(\mathbf{c})$. For DGT measurements, the vertical lines indicate the time period for the measurement, and the filled square represent the mid-date. Temporal variations of $\mathrm{Mn} / \mathrm{Ti}$ and $\mathrm{Fe} / \mathrm{Ti}$ in the suspended phase at $5 \mathrm{~m}$ depth (d).
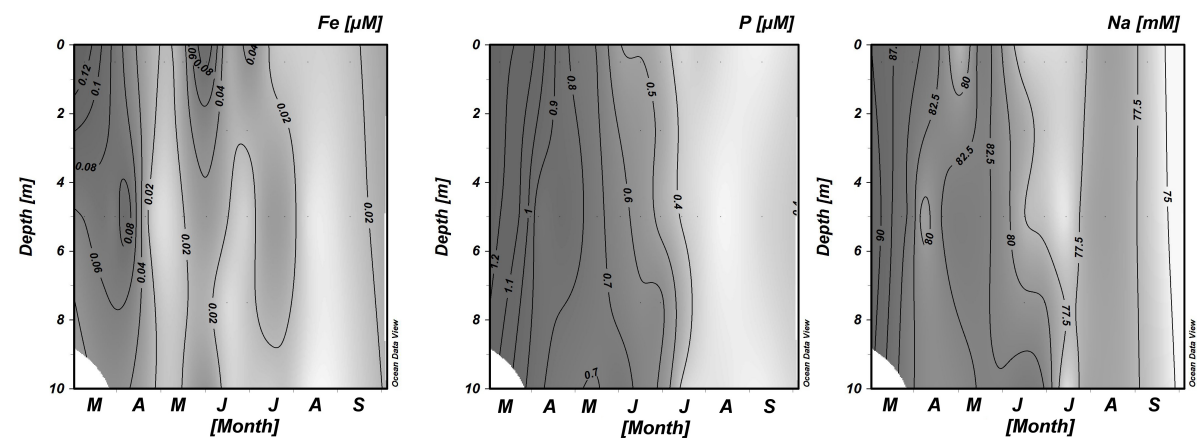

Fig. 9. Variations of total Fe (unfiltered samples), phosphorus (P) and sodium (Na) for the uppermost $10 \mathrm{~m}$ at the Landsort Deep station. This figure was prepared with Ocean Data View using DIVA gridding. for samples taken at $0.5,5$ and $10 \mathrm{~m}$ depth

\subsubsection{Iron speciation}

Changes of Fe concentrations were less pronounced compared to the other two stations (Table 1 and Fig. 13). Initial $\mathrm{TFe}$ concentrations were higher compared to measurements in the summer, with $24.4 \mathrm{nM}$ of TFe in May, deceasing to a minimum of $7 \mathrm{nM}$ in July. The DFe and SFe fractions were rather stable through the sampling period, with $3.8 \mathrm{nM}$ and $3.2 \mathrm{nM}$, respectively. A correlation between suspended $\mathrm{Fe}$ and chl- $a$ was not found at this station."

\subsection{DGT measurements}

Clearly, the average $[\mathrm{Fe}]_{\text {DGT }}$ was deceasing from the Bothnian Sea station $(1.1 \mathrm{nM})$ to about $1 / 3$, with similar concentrations at Landsort Deep and in the Gotland Deep $(0.35 \mathrm{nM})$.
During 2004 the DGT measurements at Landsort Deep were conducted at a temporal resolution, which affected the precision of the method. During the short time of deployment (23 weeks) the amount of accumulated Fe was often very low, and the blank contribution made it difficult to interpret any temporal changes in $[\mathrm{Fe}]_{\mathrm{DGT}}$, even though an average for the whole sampling period could be obtained. The DGT-labile fraction was low at all stations compared to SF (less than $10 \%$ on average, Table 1). Since the concentrations measured by DGT are calculated from diffusion coefficients, the results change if a metal is complexed by for instance fulvic acid. This will lead to a significant lower diffusion coefficient, and thus a slower diffusion. If assuming that all DGTlabile $\mathrm{Fe}\left([\mathrm{Fe}]_{\mathrm{DGT}}\right)$ was bound to fulvic acids the concentrations becomes about 5 times higher, but is still lower than 


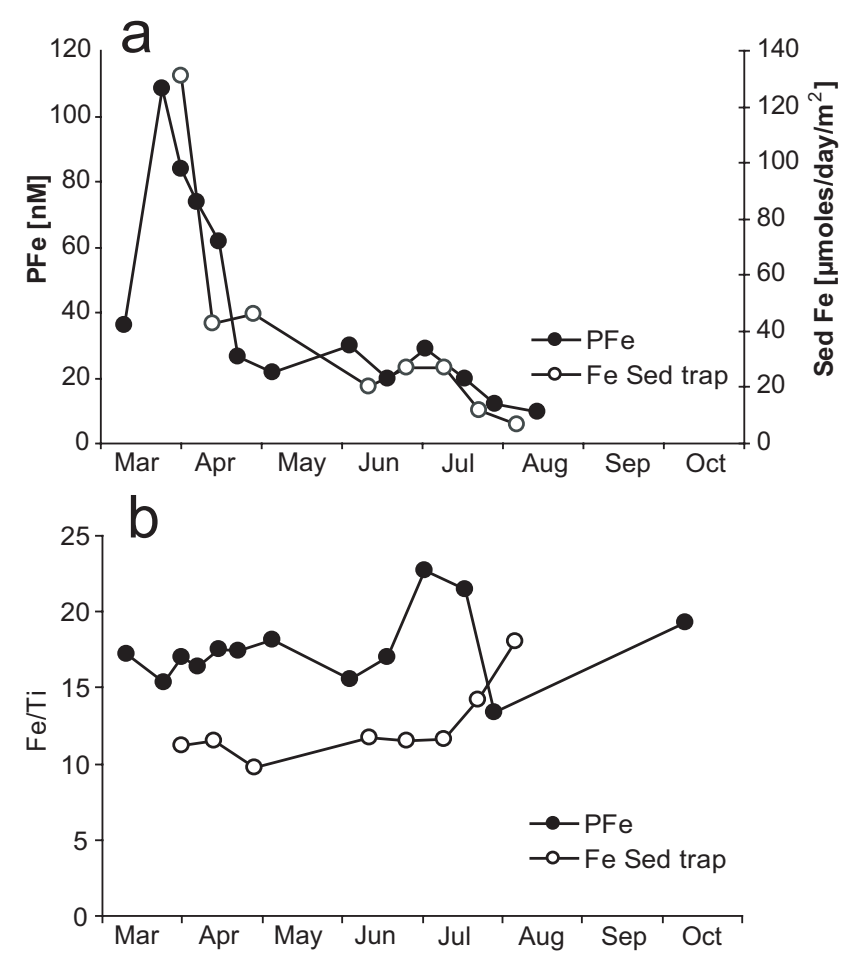

Fig. 10. Suspended Fe (PFe) at $5 \mathrm{~m}$ depth and sediment trap collected Fe at $30 \mathrm{~m}$ depth at Landsort Deep (BY31) 2004 (a). Fe/Ti in $\mathrm{PFe}$ at $5 \mathrm{~m}$ depth and in sediment trap collected material (b).

SFe. Biofuoling during long term deployments in coastal areas has been observed (Munksgaard and Parry, 2003; Dunn et al., 2003). This may change the diffusion distance, and the area of the filter exposed to solution. Organisms might also affect the concentration gradient by sorbing metal ions. However, visible biofouling was limited to very thin reddish bacterial slimes or absent during all sampling occasions, suggesting this to be a minor problem in the present study, suggesting limited permeability of the DGT membrane to specific Fe organic complexes as the main cause for the discrepancy between the SFe and DGT Fe pools.

\section{Discussion}

The aim of this study was to identify sources and sinks of $\mathrm{Fe}$ in surface waters of the Baltic Sea. We discuss the results with particular respect to the aspects of the high $\mathrm{Fe}$ concentrations measured in the spring, the role of riverine input versus deep water as sources of Fe, the observed strong correlation of PFe and chlorophyll- $a$, and the size fractionation and isotopic fractionation during $\mathrm{Fe}$ transport through the Baltic Sea. The combination of iron-isotope and FFFICPMS data yields valuable information for the identification and possible origin of the different types of colloids present in a sample. With this approach we investigate their potential importance as carriers of iron and other elements in aquatic systems.

\subsection{Fe sources to the Bothnian Sea}

Generally, the sources of the high initial Fe concentrations in the Bothnian Sea and at Landsort Deep (Figs. 4 and 8 respectively) could be primarily seasonal terrestrial input, lateral transport of water from other basins, and vertical mixing. Further, atmospheric input or diffusive flux of $\mathrm{Fe}$ may be of relatively higher importance at the more remotely located Gotland Deep Station. The turnover of water of the Bothnian Sea is mainly governed by the inflow of surface water from the Baltic Proper (Marmefelt and Omstedt, 1993), and not by thermohaline circulation. Since the most of the bottom water is renewed annually in the Bothnian Sea (Kullenberg, 1981), a considerable amount of $\mathrm{Fe}$ and associated elements are also likely to be supplied from this deep water. However, because of the coincidental peak in total $\mathrm{Fe}$ concentration and dip in salinity in the Bothnian Sea during this study (Fig. 4b) it is likely that riverine input is at least partly responsible for the elevated concentrations in May. The spring flood from Swedish rivers at the same latitude as the sampled stations peaks at this time (Bergström and Carlsson, 1994) and also the positive correlation between terrestrial biomarkers such as HS and $\varepsilon 280$ (Table 3 ) to unfiltered iron suggest terrestrial influence. The negative correlation between TFe and salinity (Fig. 4b), further supports that conditions in the Bothnian Sea are governed by mainly a two component mixing of freshwater (that has a high concentration of nutrients and $\mathrm{Fe}$ ), and seawater that is diluting the concentration of $\mathrm{Fe}$.

Although the relationship between $\mathrm{Al}$ and $\mathrm{Ti}$ appears to be almost linear for all filters collected, there are indications from our data that $\mathrm{Al}$ does not at all times have a conservative behaviour. Al may be associated with the humic fraction (Ingri et al., 2006; Warren and Haack, 2001), and since this fraction may also be a carrier for $\mathrm{Fe}, \mathrm{Al}$ can neither be regarded to always behave conservative nor to only represent the lithogenic phase. Therefore, Fe/Ti ratios are used throughout this paper as an indicator if $\mathrm{Fe}$ has a terrestrial origin. The constantly high Fe/Ti ratio ( $>23$, g/g, Table 3 ) exceeds the average crust ratio of 10.2 (Rudnick et al., 2003). If the suspended $\mathrm{Ti}$ represents lithogenic, detrital particles, then the excess $\mathrm{Fe} / \mathrm{Ti}$ (above the crustal average) represents non-detrital particles and a strong enrichment of Fe the suspended matter. The Fe/Ti ratios in $\mathrm{PFe}$ were much higher in the Bothnian Sea compared to the Landsort Deep which again indicates a more prominent riverine input.

Isotope signatures in $\mathrm{PFe}$ were positive throughout the measured period, with the lowest $\delta^{56} \mathrm{Fe}$ signal observed in May $(0.07 \%$ ) and the highest in June $(0.20 \%$; Table 4 , Fig 6a). The isotopic composition of the suspended matter shows a linear positive correlation with the Fe/Ti ratio (Fig. 6b). Ingri et al. (2006) suggest that the isotopic signature of riverine Fe-oxyhydroxides is heavy (positive $\delta^{56} \mathrm{Fe}$ ), while carbon-rich colloidal material with high $\mathrm{Fe}$ content have a negative $\delta^{56} \mathrm{Fe}$. Following this model, the suspended phase in the Bothnian Sea is dominated by oxyhydroxides. If 

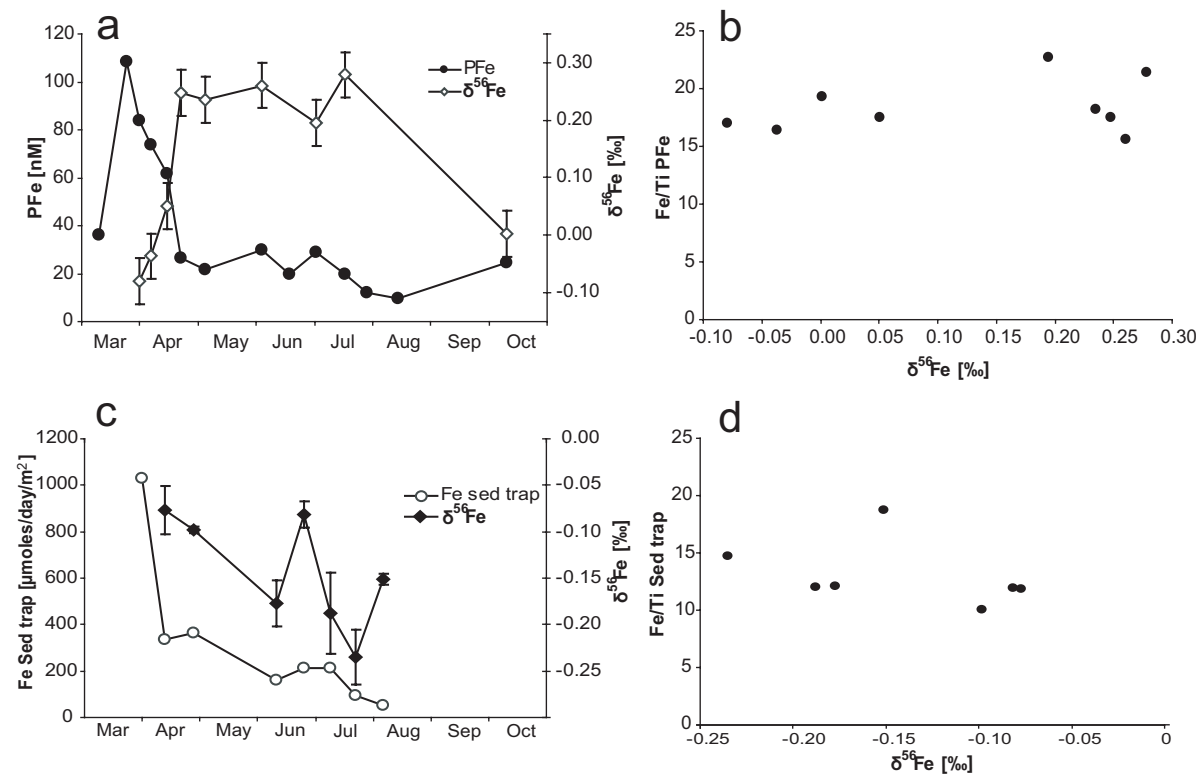

Fig. 11. Isotopic signatures of suspended $\mathrm{Fe}(\mathrm{PFe})$ at $5 \mathrm{~m}$ depth and sediment trap collected material at $30 \mathrm{~m}$ depth, all data from Landsort Deep 2004. The seasonal variation of $\delta^{56} \mathrm{Fe}$ in PFe a nd the PFe concentration (a). Error bars indicate instrumental precision \pm 2 STD of the mean. $\delta^{56} \mathrm{Fe}$ plotted against $\mathrm{Fe} / \mathrm{Ti}$ in $\mathrm{PFe}(\mathbf{b})$. Temporal variation of $\delta^{56} \mathrm{Fe}$ in sediment trap collected material and amount of sedimenting Fe (c). $\delta^{56} \mathrm{Fe}$ plotted against $\mathrm{Fe} / \mathrm{Ti}$ in the sediment trap collected material (d).
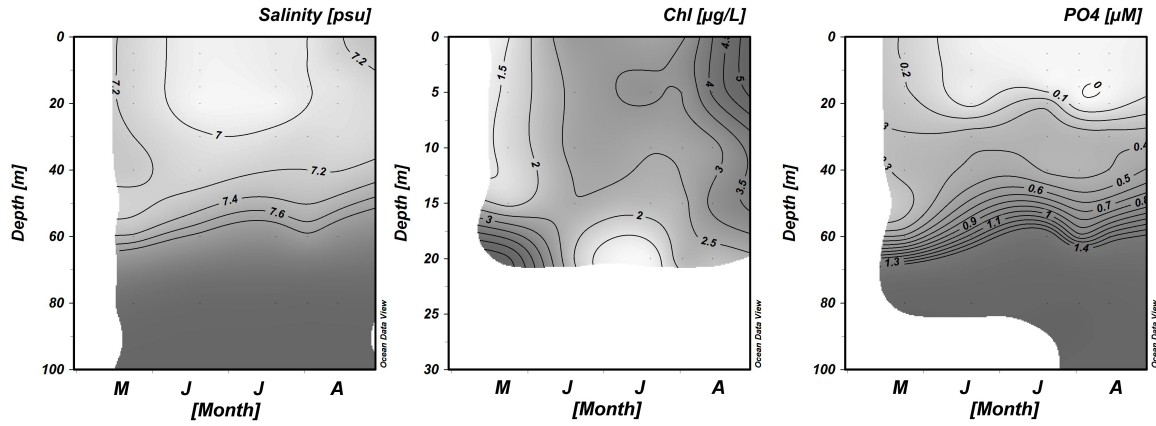

Fig. 12. Time series of salinity, density, chl- $a$ and $\mathrm{PO}_{4}^{2-}$ at the Gotland Deep station (BY15) during 2007. Note that differences in depth scale. This figure was prepared with Ocean Data View using DIVA gridding.

the regression line (Fig 6b) extrapolated to the average crust $\mathrm{Fe} / \mathrm{Ti}$ value $(10.2), \delta^{56} \mathrm{Fe}$ is approximately $-0.07 \%$, a value close to what has been measured in the Kalix river during spring flood (Ingri et al., 2006), but not similar to the composition of the average crust, which have a $\delta^{56} \mathrm{Fe}=0.09 \pm 0.05$ relative the IRMM-014 standard (Beard et al., 2003). The filters analyzed in this study were clogged to collect some of the colloidal Fe, which likely consists of the Fe-carbon rich phase and the Fe-oxyhydroxide phase (Lyvén et al., 2003). River water-seawater mixing experiments by Bergquist and Boyle (2006) indicated that aggregated Fe was enriched in heavy isotopes. Hence, aggregation and sedimentation of the oxyhydroxide fraction during estuarine mixing may remove heavy isotopes from surface suspended matter, re- sulting in a shift towards a more negative isotopic signature in the remaining suspended phase. However, here the salinity gradient is weak $(S=4.7)$ and thus significant flocculation and removal of Fe-oxyhydroxides may not to be expected. Apparently this phase is dominating to such an extent that it masks the isotopic signature from the $\mathrm{Fe}-\mathrm{C}$ colloids. In contrast, during mixing experiments Stolpe and Hassellöv (2007) concluded that most of the removal of $\mathrm{Fe}$ colloids already takes place at salinities below $2.5 \%$. While Fe-oxyhydroxides may be aggregated at the present salinity, our data suggest that they may still be present as suspended matter due to a relatively slow sedimentation. Findings in the Kalix river estuary (Gustafsson et al., 2000) indicate that the low presence of "sinkers", i.e. detrital particles, 


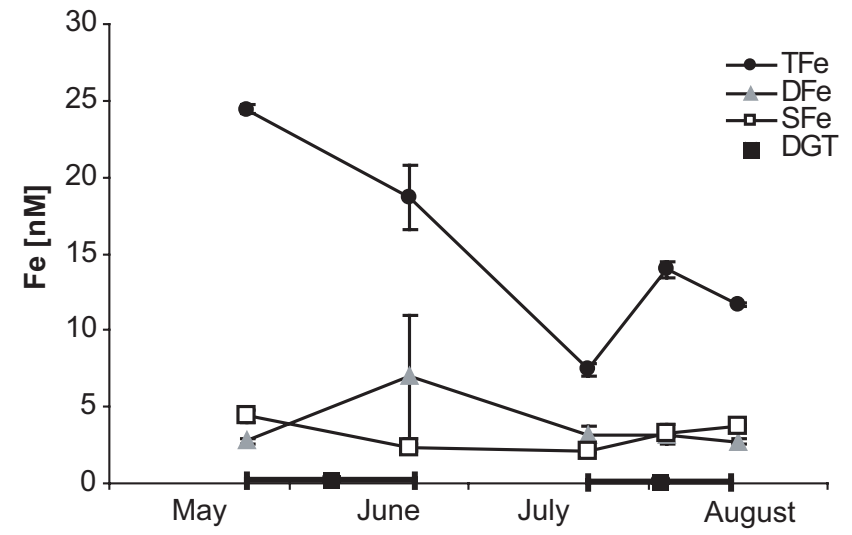

Fig. 13. Temporal variations of TFe (total Fe), DFe $(<0.22 \mu \mathrm{m})$, SFe $(<1 \mathrm{kDa})$ and DGT-labile Fe $\left([\mathrm{Fe}]_{\mathrm{DGT}}\right)$ at the Gotland Deep station (BY15) euphotic zone. For DGT measurements, the vertical lines indicate the time period for the measurement, and the filled square represent the mid-date.

inhibited sedimentation even though aggregation took place trough the salinity gradient and the situation could be similar for the Bothnian Sea. In contrast with our results, Escoube et al. (2009) found no significant isotopic fractionation of $\mathrm{Fe}$ during estuarine mixing. This clearly indicates that there is a need of more studies on the topic of Fe isotopic fractionation during land to sea transport.

At this northernmost station, the colloidal fraction of $\mathrm{Fe}$ was higher than at the two other stations (Table 2), which likely reflects colloidal $\mathrm{C}$ from riverine input. FFF-ICPMSdata (Fig. 1b) also indicate the presence of a much larger fraction of carbon-bound colloidal $\mathrm{Fe}$, compared to the two stations in the open Baltic Proper. Further, FFF-ICPMS results (Fig. 1) suggest that terrestrial fulvic acid associated $\mathrm{Fe}$ is a major colloidal component in the Baltic Sea. In addition, FFF-ICPMS detected that larger $(3-50 \mathrm{~nm})$ colloidal biopolymers form in surface seawater after periods of high primary production (Stolpe and Hassellöv, 2010). In the Bothnian Sea, although these types of biopolymers occurred during summer, iron was found to be exclusively associated to fulvic acid ( $0.5-4 \mathrm{~nm}$ size fraction) from terrestrial sources (Fig. 1b).

Similar results were obtained in surface water of the Baltic Sea, both in offshore samples (Fig. 1c) and in the coastal Baltic Proper (Fig. 1d). Data from Gotland Deep are very similar to the obtained fractogram from Landsort Deep (Fig. 1c). In contrast, in the more marine coastal system of the Gullmarsfjord on the Swedish west coast, where the influence of rivers is less strong, iron was found to associate to biopolymer nanofibrils during the summer (Fig. 1e). By the use of Atomic Force Microscopy (AFM) the sizes of these nanofibrils were determined to $50-250 \mathrm{~nm}$ in length and $0.5-1.1 \mathrm{~nm}$ in thickness and associated with TEP (Stolpe and Hassellöv, 2010).

\subsection{Fe sources to the Baltic Proper}

Likewise to the Bothnian Sea station, the Landsort Deep station is located in relatively close proximity to land. However, station Landsort Deep is far from any major river, and the average peak of riverine freshwater contribution to the Baltic Proper until April (Bergström and Carlsson, 1994). The origin of the high Fe levels at Landsort Deep in March could still be affected by direct terrestrial input, via local upwelling (Myrberg and Andrejev, 2003), or also by the transport of lower saline water from the Bothnian Sea via the southward current along the Swedish east-coast. Eilola and Stigebrandt (1998) show that the input of juvenile freshwater to the Baltic Sea (water from the Bothnian Sea) has its second highest monthly average during March. On 10 March, chl- $a$ and $\mathrm{PFe}$ were relatively low, after that chl- $a$ increased fourfold and PFe was almost tripled in two weeks time (Fig. 7). The spring bloom was followed a mid-April high in chl- $a$ and several smaller blooms, dominated by cyanobacteria (Gelting et al., 2010). Our data indicate that vertical mixing of deep water is the dominant source of $\mathrm{Fe}$ and also $\mathrm{P}$ to the euphotic zone, feeding the spring bloom.

During this study, most of the $\mathrm{Fe}$ in the surface water was already lowered considerably in April. A riverine source, as well as lateral transport of Bothnian Sea surface water, would also probably decrease the salinity and the concentrations of the major elements, not causing maximum levels as observed here. The coinciding patterns of higher concentrations of the major seawater elements (here exemplified by $\mathrm{Na}$ ) with elevated levels of $\mathrm{Fe}$ and P (Fig. 9) indicate that their supply was from intrusions of deeper laying water masses with higher salinity and not from riverine or rain input. Although the deeper water has very limited exchange to the surface, according to Rodhe (2006) the upper $5 \mathrm{~m}$ of the deep water are entrained and mixed into the surface layer of the Baltic Sea during late autumn and winter, potentially explaining the presence of high Fe concentrations in surface water in the spring. Salinity and density data (Fig. 7) further show that water column above the halocline was well mixed in March and April and support the notion that a significant fraction of the iron detected was supplied by vertical mixing with high phosphate containing underlying water masses during wintertime. In this part of the Baltic Sea, active uptake by phytoplankton has been shown to be the mechanism that decreases the amount of $\mathrm{PO}_{4}^{3-}$ during March and April and is consistent inter-annually, even though the absolute concentrations of $\mathrm{PO}_{4}^{3-}$ differ (Larsson et al., 2001).

The initial PFe at the surface water of Landsort Deep has a low $\delta^{56} \mathrm{Fe}$ and it then rapidly changed when phytoplankton bloom development alters the pool of PFe. Later in the season, between 9 and 21 September, salinity increased from 6.0 to 6.7 at $5 \mathrm{~m}$ depth, and total $\mathrm{P}$ increased from 470 to $820 \mathrm{nM}$, which indicates an event of vertical mixing and also explains the lowering of the $\delta^{56} \mathrm{Fe}$ from $+0.28 \%$ o 15 July to 
zero at 6 October (Fig. 11a). Likewise, Staubwasser (2006a) found that the composition of the PFe in the anoxic bottom waters of the Gotland Deep were about half a permille lower than the samples from oxic deep water, which were close to zero. They also presented data from the upper $50 \mathrm{~m}$, which showed the lowest $\delta^{56} \mathrm{Fe}$ values close to the surface. Further, a correlation between the $\mathrm{Fe} / \mathrm{Ti}$ ratios and the $\delta^{56} \mathrm{Fe}$ value, as for the Bothnian Sea is not apparent (Fig. 11b) and one probable reason for this is that the suspended material in the surface water of the Landsort Deep station is less homogeneous and more affected by the processes occurring in the suboxic zone. The conditions in the Bothnian Sea, on the other hand, may to a higher extent be affected by the higher load of suspended material of terrestrial origin, and by the fact that the whole water column is oxygenated. From a study of the isotopic composition of dissolved Fe in the Sheldt estuary, de Jong et al. (2007) pointed out the importance of local sinks and sources. In this context, the anoxic conditions below the halocline are of major importance, since this is a mixing of at least three different non-detrital Fe phases; including Fe oxyhydroxides, carbon-rich fulvic acid associated compounds and an anoxic phase. In contrast, the two carrier phases model with two different isotopic signatures seems to be valid in the Bothnian Sea (Ingri et al., 2006).

In the open Baltic Proper (Gotland Deep), we observed similar declining patterns of the measured $\mathrm{Fe}$ fractions as at the two less marine and lower salinity stations (Fig. 13), but the total concentrations were clearly lower. The size fractionation differs and PFe levels are much lower, while the differences between the concentrations in the DFe and SFe were less than for the Landsort Deep station (Table 1). Vertical mixing and contribution from land may be important sources of $\mathrm{Fe}$ also in this area of the Baltic Sea, but we find no clear evidence of this in our measurements. The sampling for this station started later than at the other two locations, which means that the peak in spring time would possibly have been captured better if sampling started already in March or April. Here, Staubwasser et al. (2008) also attribute a change in the isotopic composition of the suspended matter to a surface cyanobacterial bloom. The authors hypothesized that the low initial values were originating from water diffusing up from the basin margin sediments after suboxic early-diagenetic remineralization, since such a process commonly generate low $\delta^{56} \mathrm{Fe}$ values, similar to what has been described in several previous studies (Staubwasser et al., 2006b; Rouxel et al., 2008; Severmann et al., 2006). This hypothesis follows the findings of fractionation of Fe during redox processes, both by abiotic processes (Bullen et al., 2001) and microbially mediated mechanisms (Balci et al., 2006).

In addition to the supply of riverine Fe-oxyhydroxides, insitu redox cycling may cause enrichment of ${ }^{56} \mathrm{Fe}$ in surface waters. In the Baltic Proper surface water a high persistent standing stock of $\mathrm{Fe}$ (II) recently was measured in the summer (Breitbarth et al., 2009). Studies have shown that non- biogenic oxidation of $\mathrm{Fe}(\mathrm{II})$ generates Fe-oxyhydroxides enriched in ${ }^{56} \mathrm{Fe}$ (Bullen et al., 2001). If the levels of $\mathrm{Fe}(\mathrm{II})$ at the other Baltic Sea stations are similar to the standing stock of $0.25-0.5 \mathrm{nM}$ at the Gotland Deep station (Breitbarth et al., 2009), then the redox cycle of Fe in the euphotic zone may affect the isotopic composition of the suspended matter as much as the riverine input. Estimations of $\mathrm{Fe}$ (II) half-lives range in the same order of magnitude $(\sim 20-120 \mathrm{~s}$, data not shown). However as shown by Breitbarth et al. (2009) actual $\mathrm{Fe}(\mathrm{II})$ half-lives may far exceed predicted values and together with overall higher $\mathrm{Fe}$ concentrations could result in significant $\mathrm{Fe}(\mathrm{II})$ concentrations during sunlit days in the Bothnian Sea. Probably a large portion of the oxidized Fe is recycled back to $\mathrm{Fe}$ (II), but if for example $10 \%$ of all $\mathrm{Fe}$ (II) goes to formation of $\mathrm{PFe}$, this process will contribute to more than 10 nanomolar PFe per day. Likewise, this may also explain why the relation between $\delta^{56} \mathrm{Fe}$ and $\mathrm{Fe} / \mathrm{Ti}$ is not clearly correlated to salinity/freshwater input in the Bothnian Sea (compare Figs. 3 and 6a). If these $\mathrm{Fe}(\mathrm{II})$ derived PFe are sinkers, they could also be the explanation to the high rate of Fe loss due to sedimentation when the level of PFe at $5 \mathrm{~m}$ was decreasing in the summer in the Bothnian Sea.

As well for the TFE, DFe and SFe fractions, there is a terrestrial proximity-salinity dependency on the $[\mathrm{Fe}]_{\text {DGT }}$ fraction. We were able to detect a $30-40 \%$ decrease in [Fe $]_{\text {DGT }}$ from the spring towards later in the season at the Bothnian Sea and Gotland Deep stations (Table 1, Figs. 4d and 13). This change from low to higher salinity, and from spring to summer, is possibly connected to the amount of complexed Fe that changes along this gradient. Complexes between metals and fulvic acids may pass through the diffusive gel and are thus measured by the DGT technique (Scally et al., 2006), however it is not clear if other Fe complexes may be retained by the membrane. Breitbarth et al. (2009), show that the DGT labile fraction is very similar to the $\mathrm{Fe}(\mathrm{II})$ concentration at Gotland Deep during the summer of 2007, which invokes that DGT's may under sample the actual soluble Fe fraction that may be larger than the Fe(II) pool.

\subsection{Biological processes in the euphotic zone and sinks}

In the Bothnian Sea, the decline of the DFe and SFe fractions were clearly not as pronounced as the PFe fraction, but they follow a similar pattern (Fig. 4a and d). Since the particulate $\mathrm{Fe}$ phase $(\mathrm{PFe})$ is dominating the system at this station, it is motivated to further evaluate the changes in this fraction during the studied period. A strong correlation of chl- $a$ and $\mathrm{PFe}$ was observed (Fig. 4c). However, this correlation may not be driven by active phytoplankton $\mathrm{Fe}$ uptake, because stoichiometrically the Fe concentrations are much too high. Phosphorous is the limiting nutrient for the spring bloom, and is supplied to the surface waters via similar pathways as iron. Phosphorus and iron have linked hydrogeochemical pathways, especially in the suspended phase; $\mathrm{P}$ is transported 
adsorbed on or co-precipitated with $\mathrm{Fe}$ oxyhydroxides in river systems (Fox, 1989; Pokrovsky and Schott, 2002). In previous studies, the removal of dissolved $\mathrm{P}$ and Fe during estuarine aggregation has shown to be coincidental; Fe oxyhydroxides formed by aggregation at increasing salinity incorporate phosphate, which drastically diminish the dissolved $\mathrm{P}$ concentration through a salinity gradient (Gunnars et al., 2002). From our measurements in the Bothnian Sea, both particulate $\mathrm{P}$ and $\mathrm{PO}_{4}^{3-}$ are correlated to $\mathrm{PFe}\left(r^{2}=0.90\right.$ and 0.82 , respectively). Conclusively, Fe-oxyhydroxides in the Bothnian Sea act as P scavengers, and remove P from the euphotic zone, in line with findings of Gunnars et al. (2002).

Phytoplankton cells may further serve as surfaces to which iron in different forms adsorbs and is scavenged. Sediment trap data from the Bothnian Sea (data not shown), indicate a correlation between the removal of $\mathrm{C}, \mathrm{N}$ and $\mathrm{P}$ and Fe. The vertical flux of Fe to the sediment traps at the Landsort Deep were decreasing from $131 \mu$ moles $/$ day $/ \mathrm{m}^{2}$ in April to $6.9 \mu$ moles/day $/ \mathrm{m}^{2}$ in August (Fig. 10), which means that the sedimenting Fe follows roughly the same temporal trend as the $\mathrm{PFe}$ at $5 \mathrm{~m}$ depth. Data indicate an additional source of PFe during the summer, since the sum of the loss in the upper $30 \mathrm{~m}$ does not budget the amount collected in the sediment traps. Considering that sediment traps usually are underestimating the sedimenting material (Gustafsson et al., 2004), data indicate that there is a continuous, yet diminishing supply of PFe during the whole measured period and riverine input is the most probably candidate for such.

Similar to the Bothnian Sea, a correlation between chl- $a$ and particulate $\mathrm{Fe}$ was observed at the Landsort Deep, albeit only during the five first sampling occasions (Fig. 8b). Next to phytoplankton cells and cell aggregates, bloom byproducts, namely transparent exopolymer particles (TEP, Passow, 2002), may also act as Fe scavengers. However, TEP measurements did not reveal a correlation with suspended or sedimenting $\mathrm{Fe}$ (data not shown). Other phytoplankton exudates not detected by this method may be of importance though, since they exist over a continuum of size ranges (Verdugo et al., 2004), and the TEP method only measures those $>0.45 \mu \mathrm{m}$. Stolpe and Hassellöv (2010) found significant amounts of Fe associated to colloidal biopolymers in surface seawater in the Skagerrak Sea after periods of high primary production. However, FFF-ICPMS data (Fig. 1c) from the Landsort Deep station do not indicate presence of such colloids. The $\mathrm{Fe} / \mathrm{Ti}(\mathrm{g} / \mathrm{g})$ ratio in suspended matter was above 15 during the whole measured period (except on 26 July; 13.4). Considering the average crust ratio of 10.2 (Rudnick et al., 2003) this indicates an enrichment of $\mathrm{Fe}$ in the suspended matter. Elevated $\mathrm{Fe} / \mathrm{Ti}$ ratios in $\mathrm{PFe}$ on 30 June and $15 \mathrm{July}$, occur at the same time as the peak of cyanobacteria (Gelting et al., 2010), which indicate that there may be a coupling to the formation of particulate non-detrital Fe.

During the highest level of DFe (26 July, Fig. 8c), Fe/Ti in the particulate dropped to a summer minimum (Fig. 8d), which is a sign of a connection between the processes reg- ulating PFe and DFe. The reason of the sharp increase during the summer may be explained by terrestrial input of dissolved Fe, potentially bound to fulvic acid as indicated by high levels of $\varepsilon 280$ (Table 3). Lower salinity (Fig. 7) and lower concentration of the major elements (exemplified by $\mathrm{Na}$ in Fig. 9) suggest a dilution that may be caused either by fresh- or rainwater input. Measurements from the Polish coast showed that rainwater in Gdansk contained on average about $7 \mu \mathrm{mol} \mathrm{Fe} \mathrm{per} \mathrm{mm} \mathrm{of} \mathrm{precipitation} \mathrm{(data} \mathrm{from}$ Falkowska et al., 2008). If this holds for the open Baltic Sea, this is a potential major contributor of Fe. However, precipitation data from the Swedish Hydrological and Metrological Institute (SMHI) does not support this since the precipitation in late June-July does not significantly differ from the previous or subsequent periods of the summer. The increasing population of cyanobacteria during the summer may also be responsible for keeping $\mathrm{Fe}$ in solution and extract DFe from PFe by siderophore-like pathways. The cyanobacteria bloom reached its peak on 15 July (Gelting et al., 2010) and the elevated levels of DFe and SFe on 26 July could possibly origin from remineralization by cyanobacteria. The stratified conditions (Fig. 7) suggest that no vertical mixing took place at this event of high DFe in the summer.

In contrast to the water column it is notable that the $\delta^{56} \mathrm{Fe}$ value in the sedimenting material was constantly negative while the $\mathrm{Fe} / \mathrm{Ti}$ ratio was close to the average crust value of 10.2 on all except the last two occasions (Figs. 10b and 11). A PFe phase with a Fe/Ti value close to average crust ratio would be regarded as mainly composed of lithogenic particles and is predicted to have a $\delta^{56} \mathrm{Fe}$ of 0.09 (Beard et al., 2003). This was not the case here and thus the use of elemental ratios should be carefully evaluated. The suspended matter at $5 \mathrm{~m}$ depth is much more enriched in $\mathrm{Fe}$, as reflected by the higher Fe/Ti values (Fig. 10b).

In July, during the drop in $\mathrm{Fe} / \mathrm{Ti}$ in $\mathrm{PFe}$, the sediment trap data showed an increased ratio, which indicates that the particles formed at surface (high $\mathrm{Fe} / \mathrm{Ti}$ ) end up in the sediment trap with some lag in time. Furthermore, the $\delta^{56} \mathrm{Fe}$ value changed from -0.08 to +0.28 whereas the $\mathrm{Fe} / \mathrm{Ti}$ ratio was constant at approximately 16 (Fig. 11b). The general negative values of $\delta^{56} \mathrm{Fe}$ in the sediment trap seem at least initially connected to the light signature of the suspended matter at $5 \mathrm{~m}$ depth that is removed from the euphotic zone and collected in the sediment trap. The persisting negative $\delta^{56} \mathrm{Fe}$ in the sediment traps when suspended PFe in surface water is enriched in heavy Fe isotopes, appears contradictory at first hand. However, not only isotope data, but also the $\mathrm{Fe} / \mathrm{Ti}$ ratios indicate that the composition of the sedimenting material is different from the PFe in the surface and thus several mechanisms could influence its elemental composition and isotopic signature. Phytoplankton has shown to fractionate $\mathrm{Fe}$ isotopes to a relative high extent. Bergquist and Boyle (2006) measured $\delta^{56} \mathrm{Fe}$ values of $-0.24 \%$ o for Amazon plume plankton tows, where they attributed this signature to both intra- and extracellular bound Fe. Additionally, there may be 
a component of $\mathrm{Fe}$ (II) enriched in light $\mathrm{Fe}$, diffusing from the suboxic deeper water and perturbing the $\delta^{56} \mathrm{Fe}$ value of sedimenting material.

\section{Concluding remarks}

In quintessence, the Bothnian Sea water is strongly terrestrial influenced, which is reflected in the general pattern of positive $\delta^{56} \mathrm{Fe}$. This terrestrial component is enriched also in P. During phytoplankton bloom progression, $\mathrm{P}$ and $\mathrm{Fe}$ are consumed from the water, while at later stages scavenged $\mathrm{Fe}$ is lost form surface water during sedimentation. At the Landsort Deep, the water is less affected by terrestrial sources, the primary Fe sources seems to be from anoxic deep water. This is indicated by $\delta^{56} \mathrm{Fe}$ and high salinity at $\mathrm{Fe}$ maximum. $\mathrm{Fe}$ in the surface water is removed together with $\mathrm{P}$ during the spring bloom, but the levels are not depleted during the summer. For the Gotland Deep station, conditions change less marked. The conditions mostly resembles of Landsort Deep, but we have no clear signs of transport of $\mathrm{Fe}$ from the anoxic part of the water column.

We conclude three major findings from our study:

1. All three studied locations showed a steadily decreasing pattern of $\mathrm{Fe}$ in the measured fractions $\mathrm{TFe}, \mathrm{DFe}, \mathrm{SFe}$ and $[\mathrm{Fe}]_{\mathrm{DGT}}$, from the first measurement in spring towards the summer. From FFF-ICPMS measurements, a significant, but decreasing, carbon fraction (most likely fulvic acid) dominated colloid bound $\mathrm{Fe}$ at all locations. This is analogous to the findings of humic substances (HS) controlling $\mathrm{Fe}$ in the coastal and open ocean (Laglera and van den Berg, 2009).

2. The relatively high level of $\mathrm{Fe}$ in the $<1 \mathrm{kDa}$ fraction at all sampled stations (above $2 \mathrm{nM}$ ) indicate that the levels of SFe are sufficient for Fe-replete phytoplankton growth. Calculations of $\mathrm{Fe}$ uptake by Baltic phytoplankton (Breitbarth et al., 2009) are orders of magnitude lower than this number. In spite of this, a strong correlation was observed between chl- $a$ and PFe. This was not attributed to active uptake, but a common cycling of $\mathrm{Fe}$ and $\mathrm{P}$; similar sources, growth of phytoplankton onto which PFe attach and removal of PFe during sedimentation. Hence, biomass and particle formation strongly affect scavenging of Fe.

3. Iron isotope data reveal systematic temporal variations in the $\mathrm{Fe}$-isotope signature, the $\delta^{56} \mathrm{Fe}$ value changed from -0.08 to $+0.25 \%$ during three weeks in March and April at Landsort Deep. This change was related to spring-bloom (diatoms) and subsequent sedimentation of iron with a negative isotope signature. All sediment trap data from Landsort Deep showed a negative iron isotope value. During summer a relatively stable positive $\delta^{56} \mathrm{Fe}$ value was measured in suspended matter both at Bothnian Sea and at Landsort Deep. This positive value probably is a combination of river introduced aggregated oxyhydroxides and particulate iron formed from oxidation of dissolved Fe(II) in the euphotic zone. This later proposed source is connected the photochemical reduction of Fe occurring in surface waters of the Baltic Sea (Breitbarth et al., 2009). Hence, aggregated but still suspended Fe-oxyhydroxides might be spread over large areas in the Gulf of Bothnia. Iron isotope data indicate that a $\delta^{56} \mathrm{Fe}$ value around zero does not mean that the sample consist of mainly detrital rock fragments, usually the value is reflecting a mixture of iron particles with positive and negative values.

Acknowledgements. This work has been carried out with financial support from the Swedish Research Council \#621-2003-2523 and \#621-2005-3680, Swedish Research Council for Environment, Agricultural Sciences and Spatial Planning (FORMAS) \#217-20051879, Kempestiftelsen and Umeå Marine Research Center (UMF). E. B. further acknowledges funding by the German Research Foundation (DFG, BR 3794). Bernt Abrahamsson, Amund Lindberg, Leif Lundgren, Fredrik Nordblad, Carl-Henrik Stangenberg, Jakob Walve, Johan Wikner, and the crew of $M / F$ Fyrbyggaren and $R / V$ KBV005 are acknowledged for their assistance during sampling. Thanks also to Murat V. Ardelan for analyzing some of the water samples on the CL-FIA instrument. Dimitry Malinovsky, Ilia Rodushkin and ALS Scandinavia are greatly acknowledged for performing the Fe isotopic measurements. Finally, we acknowledge the two anonymous rewires for insightful comments, significantly improving the manuscript.

Edited by: K. Hunter

\section{References}

Balci, N., Bullen, T. D., Witte-Lien, K., Shanks, W. C., Motelica, M., and Mandernack, K. W.: Iron isotope fractionation during microbially stimulated $\mathrm{Fe}(\mathrm{II})$ oxidation and $\mathrm{Fe}(\mathrm{III})$ precipitation, Geochim. Cosmochim. Ac., 70, 622-639, 2006.

Beard, B. L., Johnson, C. M., Skulan, J. L., Nealson, K. H., Cox, L., and Sun, H.: Application of Fe isotopes to tracing the geochemical and biological cycling of Fe, Chem. Geol., 195, 87117, 2003.

Bergquist, B. A. and Boyle, E. A.: Iron isotopes in the amazon river system: Weathering and transport signatures, Earth. Planet. Sc. Lett., 248, 54-68, 2006.

Bergström, S. and Carlsson, B.: River runoff to the Baltic Sea: 1950-1990, Ambio, 23, 280-287, 1994.

Bianchi, T. S., Engelhaupt, E., Westman, P., Andrén, T., Rolff, C., and Elmgren, R.: Cyanobacterial blooms in the Baltic Sea: Natural or human-induced?, Limnol. Oceanogr., 45, 716-726, 2000.

Bowie, A. R., Achterberg, E. P., Mantoura, R. F. C., and Worsfold, P. J.: Determination of sub-nanomolar levels of iron in seawater using flow injection with chemiluminescence detection, Anal Chim. Acta., 361, 189-200, 1998.

Boyd, P. W., Jickells, T., Law, C. S., Blain, S., Boyle, E. A., Buesseler, K. O., Coale, K. H., Culllen, J. J., de Baar, H. J. W., Follows, M. J., Harvey, M., Lancelot, C., Levasseur, M., Owens, N. 
P. J., Pollard, R., Rivkin, R. B., Sarmiento, J., Schoemann, V., Smetacek, V., Takeda, S., Tsuda, A., Turner, S., and Watson, A. J.: Mesoscale iron enrichment experiments 1993-2005: Synthesis and future directions, Science, 315, 612-617, 2007.

Boyle, E. A., Edmond, J. M., and Sholkovitz, E. R.: The mechanism of iron removal in estuaries, Geochim. Cosmochim. Ac., 41, 1313-1324, 1977.

Breitbarth, E., Gelting, J., Walve, J., Hoffmann, L. J., Turner, D. R., Hassellöv, M., and Ingri, J.: Dissolved iron (II) in the Baltic Sea surface water and implications for cyanobacterial bloom development, Biogeosciences, 6, 2397-2420, doi:10.5194/bg-6-23972009, 2009.

Bruland, K. W., Rue, E. L., and Smith, G. J.: Iron and macronutrients in california coastal upwelling regimes: Implications for diatom blooms, Limnol. Oceanogr., 46, 1661-1674, 2001.

Brügmann, L., Bernard, P. C., and van Grieken, R.: GeoChemistry of suspended matter from the Baltic Sea 2. Results of bulk trace metal analysis by aas, Mar. Chem., 38, 303-323, 1992.

Bullen, T. D., White, A. F., Childs, C. W., Vivit, D. V., and Schulz, M. S.: Demonstration of significant abiotic iron isotope fractionation in nature, Geology, 29, 699-702, 2001.

Chin, Y.-P., Aiken, G., and O'Loughlin, E.: Molecular weight, polydispersity, and spectroscopic Properties of aquatic humic substances, Environ. Sci. Technol., 28, 1853-1858, 1994.

Dahlqvist, R., Andersson, K., Ingri, J., Larsson, T., Stolpe, B., and Turner, D.: Temporal variations of colloidal carrier phases and associated trace elements in a boreal river, Geochim. Cosmochim. Ac., 71, 5339-5354, 2007.

Dai, M.-H. and Martin, J.-M.: First data on trace metal level and behaviour in two major arctic river-estuarine systems $(\mathrm{Ob}$ and Yenisey) and in the adjacent Kara Sea, Russia, Earth. Planet. Sc. Lett., 131, 127-141, 1995.

Davison, W. and Zhang, H.: In situ speciation measurements of trace components in natural waters using thin-film gels, Nature, 367, 546-548, 1994.

Dyrssen, D. and Kremling, K.: Increasing hydrogen sulfide concentration and trace metal behavior in the anoxic Baltic waters, Mar. Chem., 30, 193-204, 1990.

de Baar, H. J. W., Boyd, P. W., Coale, K. H., Landry, M. R., Tsuda, A., Assmy, P., Bakker, D. C. E., Bozec, Y., Barber, R. T., Brzezinski, M., A., Buesseler, K. O., Boye, M., Croot, P. L., Gervais, F., Gorbunov, M. Y., Harrison, P., J., Hiscock, W., T., Laan, P., Lancelot, C., Law, C. S., Levasseur, M., Marchetti, A., Millero, F. J., Nishioka, J., Nojiri, Y., van Oijen, T., Riebesell, U., Rijkenberg, M. J. A., Saito, H., Takeda, S., Timmermans, K. R., Veldhuis, M. J. W., Waite, A. M., and Wong, C. S.: Synthesis of iron fertilization experiments: From the iron age in the age of enlightenment, J. Geophys. Res., 110,doi:10.1029/2004JC002601, 2005.

de Jong, J., Schoemann, V., Tison, J.-L., Becquevort, S., Masson, F., Lannuzel, D., Petit, J., Chou, L., Weis, D., and Mattielli, N.: Precise measurement of Fe isotopes in marine samples by multi-collector inductively coupled plasma mass spectrometry (mc-icp-ms), Anal. Chim. Acta., 589, 105-119, 2007.

Dunn, R. J. K., Teasdale, P. R., Warnken, J., and Schleich, R. R.: Evaluation of the diffusive gradient in a thin film technique for monitoring trace metal concentrations in estuarine waters, Environ. Sci. Technol., 37, 2794-2800, 2003.
Eilola, K. and Stigebrandt, A.: Spreading of juvenile freshwater in the Baltic Proper, J. Geophys. Res., 103, 27795-27807, 1998.

Escoube, R., Rouxel, O. J., Sholkovitz, E., and Donard, O. F. X.: Iron isotope systematics in estuaries: The case of north river, massachusetts (usa), Geochim. Cosmochim. Ac., 73, 4045-4059, 2009.

Falkowska, L., Lewandowska, A., Sikorowicz, G., Bełdowska, M., and Madeja, J. H.: The role of air masses on iron concentrations in wet atmospheric deposition over the urbanized coastal zone of the Gulf of Gdañsk, Oceanol. Hydrobiol. St., 37, 21-37, 2008.

Finni, T., Kononen, K., Olsonen, R., and Wallström, K.: The history of cyanobacterial blooms in the Baltic Sea, Ambio, 30, 172-178, 2001.

Fox, L. E.: A model for inorganic control of phosphate concentrations in river waters, Geochimica et Cosmochimica Acta, 53, 417-428, 1989.

Garmo, Ø., Naqvi, K., Røyset, O., and Steinnes, E.: Estimation of diffusive boundary layer thickness in studies involving diffusive gradients in thin films (dgt), Anal. Bioanal. Chem., 386, 22332237, 2006.

Gauthier, T. D., Seitz, W. R., and Grant, C. L.: Effects of structural and compositional variations of dissolved humic materials on pyrene koc values, Environ. Sci. Tech., 21, 243-248, 1987.

Gelting, J., Walve, J., Jonsson, M., Larsson, U., and Ingri, J.: Metal to carbon ratios in Baltic Sea filamentous cyanobacteria, in preparation, 2010.

Giddings, J. C.: Field-flow fractionation: Analysis of macromolecular, colloidal, and particulate materials, Science, 260, 14561465, 1993.

Guieu, C., Huang, W. W., Martin, J.-M., and Yong, Y. Y.: Outflow of trace metals into the Laptev Sea by the Lena River, Mar. Chem., 53, 255-267, 1996.

Gunnars, A., Blomqvist, S., Johansson, P., and Andersson, C.: Formation of $\mathrm{Fe}(\mathrm{III})$ oxyhydroxide colloids in freshwater and brackish seawater, with incorporation of phosphate and calcium, Geochim. Cosmochim. Ac., 66, 745-758, 2002.

Gustafsson, Ö., Widerlund, A., Andersson, P. S., Ingri, J., Roos, P., and Ledin, A.: Colloid dynamics and transport of major elements through a boreal river - brackish bay mixing zone, Mar. Chem., 71, 1-21, 2000.

Gustafsson, Ö., Nilsson, N., and Bucheli, T. D.: Dynamic colloidwater partitioning of pyrene through a coastal Baltic spring bloom, Environ. Sci. Technol., 35, 4001-4006, 2001.

Gustafsson, Ö., Andersson, P., Roos, P., Kukulska, Z., Broman, D., Larsson, U., Hajdu, S., and Ingri, J.: Evaluation of the collection efficiency of upper ocean sub-photic-layer sediment traps: a 24-month in situ calibration in the open Baltic Sea using 234th, Limnol. Oceanogr.-Meth., 62-74, 2004.

Hassellöv, M., Lyvén, B., Haraldsson, C., and Sirinawin, W.: Determination of continuous size and trace element distribution of colloidal material in natural water by on-line coupling of flow fieldflow fractionation with ICPMS, Anal. Chem., 71, 3497-3502, 1999.

Hassellöv, M. and von der Kammer, F.: Iron oxides as geochemical nanovectors for metal transport in soil-river systems, Elements, 4, 401-406, 2008.

Hutchins, D. A. and Bruland, K. W.: Iron-limited diatom growth and si:N uptake ratios in a coastal upwelling regime, Nature, 393, 561-564, 1998. 
Ingri, J., Nordling, S., Larsson, J., Rönnegård, J., Nilsson, N., Rodushkin, I., Dahlqvist, R., Andersson, P., and Gustafsson, Ö.: Size distribution of colloidal trace metals and organic carbon during a costal bloom in the Baltic Sea, Mar. Chem., 91, 117-130, 2004.

Ingri, J., Malinovsky, D., Rodushkin, I., Baxter, D. C., Widerlund, A., Andersson, P., Gustafsson, O., Forsling, W., and Ohlander, B.: Iron isotope fractionation in river colloidal matter, Earth. Planet. Sc. Lett., 245, 792-798, 2006.

Kahru, M., Savchuk, O. P., and Elmgren, R.: Satellite measurements of cyanobacterial bloom frequency in the Baltic Sea: interannual and spatial variability, Mar. Biol., 343, 15-23, 2007.

Kononen, K., Kuparinen, J., Mäkelä, K., Laanemets, J., and Pavelson, J.: Initiation of cyanobacterial blooms in a frontal region at the entrance to the gulf of finland, Baltic Sea, Limnol. Oceanogr., 41, 98-112, 1996.

Koroleff, F.: Determination of nutrients, in: method of seawater analysis, Second edition ed., edited by: Grassoff, K., Ehrhardt, M., and Kremling, K., Verlag Chemie, Weinheim, 125-139, 162-173, 1983.

Kullenberg, G.: Physical Oceanography, in: The Baltic Sea, edited by: Voipio, A., Elsevier, 135-182, 1981.

Kustka, A. B., Carpenter, E. J., and Sanudo-Wilhelmy, S. A.: Iron and marine nitrogen fixation: progress and future directions, Res. Microbiol, 153, 255-262, 2002.

Laglera, L. M. and van den Berg, C. M. G.: Evidence for geochemical control of iron by humic substances in seawater, Limnol. Oceanogr., 54, 610-619, 2009.

Larsson, J., Ingri, J., and Gustafsson, Ö.: Evaluation and optimization of two complementary cross-flow ultrafiltration systems toward isolation of coastal surface water colloids, Environ. Sci. Technol., 36, 2236-2241, 2002.

Larsson, U., Elmgren, R., and Wulff, F.: Eutrophication and the Baltic Sea: causes and consequences, Ambio, 14, 9-14, 1985.

Larsson, U., Blomgvist, S., and Abrahamsson, B.: A new sediment trap system, Marine Ecology Progress Series, 31, 205-207, 1986.

Larsson, U., Hajdu, S., Walve, J., and Elmgren, R.: Baltic sea nitrogen fixation estimated from the summer increase in upper mixed layer total nitrogen, Limnol. Oceanogr., 46, 811-820, 2001.

Lyvén, B., Hassellöv, M., Turner, D. R., Haraldsson, C., and Andersson, K.: Competition between iron- and carbon-based colloidal carriers for trace metals in a freshwater assessed using flow fieldflow fractionation coupled to icpms, Geochim. Cosmochim. Ac., 67, 3791-3802, 2003.

Malinovsky, D., Stenberg, A., Rodushkin, I., Andren, H., Ingri, J., Öhlander, B., and Baxter, D. C.: Performance of high resolution mc-icp-ms for Fe isotope ratio measurements in sedimentary geological materials, J. Anal. Atom. Spectrom., 18, 687-695, 2003.

Marmefelt, E. and Omstedt, A.: Deep water Properties in the Gulf of Bothnia, Cont. Shelf. Res., 13, 169-187, 1993.

Morrison, M. A. and Benoit, G.: Filtration artifacts caused by overloading membrane filters, Environ. Sci. Tech., 35, 3774-3779, 2001.

Munksgaard, N. C. and Parry, D. L.: Monitoring of labile metals in turbid coastal seawater using diffusive gradients in thin-films, The Journal of Environmental Monitoring, 5, 145-149, 2003.

Myrberg, K. and Andrejev, O.: Main upwelling regions in the Baltic Sea-a statistical analysis based on three-dimensional modelling, Boreal. Environ. Res., 8, 97-112, 2003.
Passow, U.: Transparent exopolymer particles (TEP) in aquatic environments, Prog. Oceangr., 55, 287-333, 2002.

Pohl, C., Loffler, A., and Hennings, U.: A sediment trap flux study for trace metals under seasonal aspects in the stratified Baltic Sea (Gotland Basin; 57 $19,20^{\prime} \mathrm{N} ; 20^{\circ} 03,00^{\prime} \mathrm{E}$ ), Mar. Chem., 84, 143-160, 2004.

Pohl, C. and Hennings, U.: The coupling of long-term trace metal trends to internal trace metal fluxes at the oxic-anoxic interface in the Gotland Basin ( $\left.57^{\circ} 19,20^{\prime} \mathrm{N} ; 20^{\circ} 03,00^{\prime} \mathrm{E}\right)$ Baltic Sea, J. Marine Sys., 56, 207-225, 2005.

Pohl, C., Loffler, A., Schmidt, M., and Seifert, T.: A trace metal (Pb, $\mathrm{Cd}, \mathrm{Zn}, \mathrm{Cu}$ ) balance for surface waters in the eastern Gotland Basin, Baltic Sea, J. Marine Syst., 60, 381-395, 2006.

Pokrovsky, O. S. and Schott, J.: Iron colloids/organic matter associated transport of major and trace elements in small boreal rivers and their estuaries (NW Russia), Chem. Geol., 190, 141-179, 2002.

Rodhe, J.: The Baltic and north seas: a process-oriented review of the physical oceonography, in: the sea, volume 11, the Global Coastal Ocean, edited by: Robinson, A. R. and Brink, K. H., Harvard University Press, 699-732, 2006.

Rodushkin, I. and Ruth, T.: Determination of trace metals in estuarine and sea-water reference materials by high resolution inductively coupled plasma mass spectrometry, J. Anal. Atom. Spectrom., 12, 1181-1185, 1997.

Rouxel, O., Sholkovitz, E., Charette, M., and Edwards, K. J.: Iron isotope fractionation in subterranean estuaries, Geochim. Cosmochim. Ac., 72, 3413-3430, 2008.

Rudnick, R. L., Gao, S., Heinrich, D. H., and Karl, K. T.: Composition of the continental crust, in: Treatise on geoChemistry, Pergamon, Oxford, 1-64, 2003.

Rue, E. L. and Bruland, K. W.: Complexation of iron(III) by natural organic ligands in the central north pacific as determined by a new competitive ligand equilibration/adsorptive cathodic stripping voltammetric method, Mar. Chem., 50, 117-138, 1995.

Sanudo-Wilhelmy, S. A., Kustka, A. B., Gobler, C. J., Hutchins, D. A., Yang, M., Lwiza, K., Burns, J., Capone, D. G., Raven, J. A., and Carpenter, E. J.: Phosphorus limitation of nitrogen fixation by trichodesmium in the central atlantic ocean, Nature, 411, 6669, 2001.

Scally, S., Davison, W., and Zhang, H.: Diffusion coefficients of metals and metal complexes in hydrogels used in diffusive gradients in thin films, Anal. Chim. Acta., 558, 222-229, 2006.

Severmann, S., Johnson, C. M., Beard, B. L., and McManus, J.: The effect of early diagenesis on the $\mathrm{Fe}$ isotope compositions of porewaters and authigenic minerals in continental margin sediments, Geochim. Cosmochim. Ac., 70, 2006-2022, 2006.

Shiller, A. M. and Boyle, E. A.: Trace elements in the mississippi river delta outflow region: behavior at high discharge, Geochim. Cosmochim. Ac., 55, 3241-3251, 1991.

Stal, L. J., Staal, M., and Villbrandt, M.: Nutrient control of cyanobacterial blooms in the Baltic Sea, Aquat. Microb. Ecol., 18, 165-173, 1999.

Stal, L. J., Albertano, P., Bergman, B., Brockel, K. v., Gallon, J. R., Hayes, P. K., Sivonen, K., and Walsby, A. E.: Basic: Baltic sea cyanobacteria. An investigation of the structure and dynamics of water blooms of cyanobacteria in the Baltic Sea-responses to a changing environment, Cont. Shelf. Res., 23, 1695-1714, 2003. 
Staubwasser, M., Schoenberg, R., von Blanckenburg, F., and Pohl, C.: Iron isotopes in marine particles from the Baltic Sea a profile from the anoxic bottom to the sea surface, American Geophysical Union, Fall Meeting, San Fransisco, 2006a.

Staubwasser, M., von Blanckenburg, F., and Schoenberg, R.: Iron isotopes in the early marine diagenetic iron cycle, Geology, 34, 629-632, 2006b.

Staubwasser, M., Schönberg, R., von Blanckenburg, F., Pohl, C., and Kruger, S.: Distribution of iron isotopes in dissolved and particulate iron from the anoxic gotland basin in the the Baltic Sea, AGU 2008 Fall Meeting, San Fransisco, 2008.

Stolpe, B., Hassellöv, M., Andersson, K., and Turner, D. R.: High resolution icpms as an on-line detector for flow field-flow fractionation; multi-element determination of colloidal size distributions in a natural water sample, Anal. Chim. Acta., 535, 109-121, 2005.

Stolpe, B. and Hassellöv, M.: Changes in size distribution of fresh water nanoscale colloidal matter and associated elements on mixing with seawater, Geochim. Cosmochim. Ac., 71, 3292-3301, 2007.

Stolpe, B. and Hassellöv, M.: Nanofibrils and other colloidal biopolymers binding trace elements in coastal seawater: significance for variations in element size distributions, Limnol. Oceanogr., 55, 187-202, 2010.
Stolte, W., Balode, M., Carlsson, P., Grzebyk, D., Janson, S., Lips, I., Panosso, R., Ward, C. J., and Graneli, E.: Stimulation of nitrogen-fixing cyanobacteria in a Baltic Sea plankton community by land-derived organic matter or iron addition, Mar. Ecol.Prog. Ser., 327, 71-82, 2006.

Verdugo, P., Alldredge, A. L., Azam, F., Kirchman, D. L., Passow, U., and Santschi, P. H.: The oceanic gel phase: a bridge in the dom-pom continuum, Mar. Chem., 92, 67-85, 2004.

Warnken, K. W., Zhang, H., and Davison, W.: Accuracy of the diffusive gradients in thin-films technique: diffusive boundary layer and effective sampling area considerations, Anal. Chem., 78, 3780-3787, 2006.

Warren, L. A. and Haack, E. A.: Biogeochemical controls on metal behaviour in freshwater environments, Earth.-Sci. Rev., 54, 261320, 2001.

Whitfield, M.: Interactions between phytoplankton and trace metals in the ocean, in: advances in marine biology, Academic Press, 1$128,2001$.

Ödman, F., Ruth, T., and Ponter, C.: Validation of a field filtration technique for characterization of suspended particulate matter from freshwater, Part i. Major elements1, App. GeoChem., 14, 301-317, 1999.

Özturk, M., Steinnes, E., and Sakshaug, E.: Iron speciation in the trondheim fjord from the perspective of iron limitation for phytoplankton, Estuarine, Coastal and Shelf Science, 55, 197-212, 2002. 